\title{
Strategi TIK untuk Meningkatkan Peringkat Webometric Universitas Riau Menggunakan Metode Gap Analysis
}

\author{
Ibnu Daqiqil Id*, Yanti Andriani, Evfi Mahdiyah, Al Aminuddin \\ Program Studi Sistem Informasi, Fakultas Matematika dan Ilmu Pengetahuan Alam, Universitas Riau \\ Kampus Bina Widya Km 12,5 Simpang Baru Pekanbaru 28293 - Indonesia \\ *email: ibnu.daqiqil@lecturer.unri.ac.id
}

(received: 4 Januari 2021, revised: 26 Maret 2021, accepted: 9 April 2021)

\begin{abstract}
Abstrak
Webometrics merupakan sistem pemeringkatan Perguruan Tinggi berbasis website yang dapat digunakan sebagai indikator kinerja global sebuah universitas. UNRI sebagai institusi yang memiliki visi untuk menjadi universitas yang unggul di bidang riset terus berupaya meningkatkan peringkat Webometrics-nya. Namun dalam beberapa dekade terakhir, peringkat Webometric UNRI menurun dari peringkat 8 menjadi peringkat 35 dalam dua tahun terakhir. Oleh karena itu, penelitian ini bertujuan untuk melakukan analisis dan benchmark sehingga dihasilkan strategi TIK untuk meningkatkkan peringkat Webometric UNRI berdasarkan permasalahan yang dialami menggunakan metode SWOT dan Gap Analysis. Beberapa faktor utama yang menyebabkan menurunnya peringkat Webometric di antaranya adalah kurang efektifnya mekanisme tata kelola website sehingga banyak konten-konten yang tidak dapat diindek dengan baik oleh mesin pencari. Selain itu perubahan metodelogi penilaian Webometric juga memberikan pengaruh, dimana pada tahun 2019 Webometric menyeimbangkan porsi komponen aktifitas dan impact website. Hasil penelitian ini menghasilkan beberapa strategi yang kemudian diturunkan menjadi rencana aksi untuk meningkatkan peringkat UNRI di antaranya penguatan tata kelola website, implementasi kebijakan SEO dan Open Access, dan penggunaan aplikasi MY UNRI sebagai media berbagi tautan untuk meningkatkan nilai Visibility. Setelah melakukan implementasi beberapa strategi tersebut, maka peringkat Webometric UNRI periode Januari 2021 mengalami peningkatan dari peringkat 35 menjadi 31.
\end{abstract}

Kata Kunci: Analisa Gap,Peringkat Universitas, SEO, Strategi TIK, SWOT, Webometric

\begin{abstract}
Webometrics is the largest academic ranking of Higher Education Institutions by analyzing publicly available web data, combining the variables into a composite indicator, and with truly global coverage. UNRI, as Higher Education Institutions that has the vision to excel in research continues to strive to improve its webometrics ranking. However, in the last few decades, UNRI's Webometrics ranking has declined. This study aims to carry out analysis, benchmarks, and ICT strategy formulation to increase UNRI's ranking using SWOT and gap analysis. Some of the main factors that caused this decline in ranking include the ineffective website governance mechanism that causes much content to be indexed properly by search engines. Besides, the changes of the Webometrics ranking methodology also affect, wherein 2019 the Webometrics balance the portion of the activity component and website impact. The proposed strategy is implemented in the action plan to increase UNRI Webometric rank. Therefore strengthening website governance is very important to increase activity and implementation of SEO, Open Access policies, and the usage of MY UNRI, which are expected to increase the Impact and Excellence of UNRI. The result of these strategies is an improvement on UNRI Webometric Rank in January 2020 from $35^{\text {th }}$ to $31^{\text {th }}$.
\end{abstract}

Keywords: Gap Analysis, Higher Education Institutions Rank, ICT Strategy, SEO,SWOT, Webometrics 


\section{Pendahuluan}

Pada era informasi ini, Internet merupakan salah satu sumber informasi utama dan website merupakan salah satu media utama yang digunakan mendiseminasikan atau menyebarkan informasi secara efektif kepada audien dengan cakupannya luas. Bagi institusi pendidikan, khususnya Universitas Riau (UNRI), website memiliki peran penting dalam mengkomunikasikan pencapaian publikasi, hasil riset, prestasi akademik/non-akademik dan juga pelestarian kebudayaan. Selain itu, website juga merupakan refleksi kualitas akademik sebuah institusi pendidikan/universitas[1]. Oleh karena itu, berbagai organisasi menciptakan metode pengukuran kualitas website antara lain yang dilakukan oleh Webometric (Spanyol) , 4ICU (Australia) dan Edoroute untuk mengukur kualitas sebuah universitas.

Salah satu peringkatan yang populer dan terbesar [2] di Indonesia adalah Webometric. Metode pemeringkatan ini dikembangkan pada tahun 2004 oleh Cybermetrics Lab, sebuah kelompok penelitian milik Consejo Superior de Investigaciones Científicas (CSIC), sebuah badan penelitian publik terbesar di Spanyol. Metodologi yang dikembangkan adalah dengan melakukan analisis kuantitatif Internet dan konten website, khusus yang berkaitan repositori penelitian ilmiah sebuah universitas [3]. Pemeringkatan ini menekankan pada indikator Presence $(\mathrm{P})$ yaitu jumlah halaman dari repositori institusi yang ditemukan dari mesin pencari, Visibility (V) yaitu jumlah link eksternal, Transparency $(\mathrm{T})$ yaitu jumlah sitasi dari penulis yang berada pada peringkat 210 teratas, serta Excellence (E) yaitu jumlah paper ilmiah milik insititusi yang ditemukan pada database Google Scholar [4].

Saat ini, website UNRI dengan domain unri.ac.id telah masuk dalam peringkatan Webometric. Peringkat UNRI menurut Webometric ditunjukkan oleh tabel 1. Sejak tahun 2013 sampai 2018 peringkat UNRI menunjukkan peningkatan baik di Indonesia dan dunia. Faktor Presence UNRI menunjukkan peningkatan yang cukup signifikan dalam 7 tahun terakhir, namun faktor Openness mengalami penurunan drastis dalam waktu 5 tahun. Namun, pada tahun 2019 dan tahun 2020 UNRI mengalami penurunan yang cukup drastis dari peringkat 8 , ke peringkat 22 dan 35 dalam waktu dua tahun. Selain itu, menurut data Sinta, jumlah publikasi dan sitasi nasional maupun internasional UNRI pada tahun 2013 sampai 2020 menunjukkan peningkatan yang cukup signifikan tetapi faktor Openness dan Excellence cenderung turun.

Tabel 1. Peringkat Webometric Unri tahun 2013-2020

\begin{tabular}{rcrrrrr}
\hline Tahun & $\begin{array}{c}\text { Peringkat di } \\
\text { Indonesia }\end{array}$ & $\begin{array}{c}\text { Peringkat } \\
\text { di Dunia }\end{array}$ & \multicolumn{5}{c}{ Kriteria } \\
\cline { 5 - 7 } & 35 & 3327 & Presence & Impact & Openness & Excellence \\
\hline $\mathbf{2 0 2 0}$ & 22 & 3058 & 1114 & 5281 & 3459 & 3310 \\
\hline $\mathbf{2 0 1 9}$ & 8 & 2579 & 1046 & 3808 & 3434 & 2933 \\
\hline $\mathbf{2 0 1 8}$ & 8 & 2007 & 1585 & 1296 & 3429 & 3097 \\
\hline $\mathbf{2 0 1 7}$ & 19 & 2128 & 1312 & 3711 & 464 & 3826 \\
\hline $\mathbf{2 0 1 5}$ & 21 & 2185 & 2238 & 2892 & 841 & 3842 \\
\hline $\mathbf{2 0 1 4}$ & 50 & 3827 & 2844 & 4586 & 3077 & 3676 \\
\hline $\mathbf{2 0 1 3}$ & & & & &
\end{tabular}

Selain tidak selarasnya antara fakta dan ranking Webometric UNRI, fenomena menarik lainnya adalah Webometric sering mengganti metode pemeringkatannya dan sumber data penilaian. Pada periode Juni 2019, Webometric telah mengganti metode penilaiannya dimana bobot penilaian menjadi 5\% dari 20\%, Visibility menjadi 50\%, Transparency menjadi 10\% dari 15\%, dan Excellence menjadi $35 \%$ dari $15 \%$. Hal tersebut jelas sangat berpengaruh terhadap peringkat UNRI. Sebagai contoh, pada tabel 1, dalam dua tahun terakhir sangat jelas bahwa faktor Presence dan Impact terus meningkat, tetapi peringkat UNRI merosot secara drastis. Hal ini karena nilai bobot presence selalu menurun, sehingga peningkatan faktor ini tidak meningkatkan peringkat UNRI. Selain itu faktor Openness terjadi penurunan $1200 \%$ dalam 5 tahun, namun faktanya tingkat sitasi UNRI selalu bertambah.

Oleh karena itu, tujuan penelitian ini adalah untuk merancang sebuah strategi TIK (Teknologi Informasi dan Komunikasi) yang dapat dilakukan untuk meningkatkan peringkat Webometric UNRI. Untuk itu, pada penelitian ini dilakukan analisis permasalahan penyebab turunnya peringkat serta pengaruh perubahan metode Webometric terhadap peringkat UNRI. Selanjutnya pada penelitian ini 
juga dilakukan perbandingan (benchmark) terhadap perguruan tinggi yang memiliki ranking yang lebih baik sehingga dapat ditentukan strategi TIK yang tepat untuk meningkatkan peringkat UNRI.

\section{Tinjauan Literatur}

\subsection{Pemeringkatan Perguruan Tinggi}

Menurut Kamus Besar Bahasa Indonesia (KBBI), arti kata pemeringkatan adalah proses, cara, perbuatan memeringkatkan. Pemeringkatan berasal dari kata dasar peringkat yang artinya adalah tingkat. Peringkat juga dapat diartikan hubungan antara sekumpulan item sedemikian rupa sehingga untuk dua item, item yang pertama memiliki hubungan "lebih tinggi dari" atau "lebih rendah dari" dan atau "sama dengan" yang item kedua [5]. Dalam matematika, ini dikenal sebagai urutan lemah atau kuat urutan objek. Jika dua item memiliki peringkat yang sama, maka dianggap seri.

Namun bagi sebuah perguruan tinggi atau universitas, peringkat merupakan alat untuk melakukan asessment terhadap institusi, menggambarkan performa riset serta alat untuk mengadopsi strategi nasional dan internasional [6]. Ada banyak metode digunakan untuk mengukur peringkat sebuah universitas di antaranya Webometric, ARWU, HEEACT, dan QS-THES. Aguillo dalam [7] membuat perbandingan berbagai model pemeringkatan dalam enam kriteria di antaranya pengajaran, internasionalisasi, ukuran, riset, dampak, dan prestise. Perbandingan metode pada Gambar 1, menunjukkan bahwa Webometric merupakan metode pemeringkatan terbesar dan telah mencakup aspek konten dan impact dari universitas tersebut.

\begin{tabular}{|c|c|c|c|c|c|c|c|c|}
\hline \multirow{4}{*}{\begin{tabular}{|l} 
CRITERIA \\
$\begin{array}{l}\text { Univs analysed } \\
\text { Univs ranked }\end{array}$ \\
\end{tabular}} & \multirow{2}{*}{\multicolumn{2}{|c|}{\begin{tabular}{|c|} 
WEBOMETRICS \\
Spain (research lab) \\
\end{tabular}}} & \multirow{2}{*}{\multicolumn{2}{|c|}{$\frac{\text { ARWU }}{\text { hina (university) }}$}} & \multicolumn{2}{|l|}{ HEEACT } & \multicolumn{2}{|l|}{ QS-THES } \\
\hline & & & & & Taiwan (gov agen & cy) & United Kingdom (fi & $\mathrm{rm})$ \\
\hline & 17000 & & 3000 & & 3500 & & 2000 & \\
\hline & 6000 & & 500 & & 500 & & $500+$ & \\
\hline Teaching & & & Alumni Nobel & $10 \%$ & & & Students/Staff & $20 \%$ \\
\hline Internatio- & & & & & & & \% Foreign Students & $5 \%$ \\
\hline nalisation & & & & & & & \% Foreign Professors & $5 \%$ \\
\hline Size & Webpages & $20 \%$ & University & $10 \%$ & & & & \\
\hline Research & $\begin{array}{l}\text { Documents } \\
\text { Papers GS }\end{array}$ & $\begin{array}{l}15 \% \\
15 \%\end{array}$ & $\begin{array}{l}\text { Nature\&Science } \\
\text { Papers S\&SSCI }\end{array}$ & $\begin{array}{l}20 \% \\
20 \%\end{array}$ & Papers S\&SSCI & $20 \%$ & & \\
\hline Impact & Links & $50 \%$ & $\begin{array}{l}\text { Highly Cited } \\
\text { Researchers }\end{array}$ & $20 \%$ & $\begin{array}{l}\text { Highly Cited Res } \\
\text { Cit High IF Journals } \\
\text { Citations S\&SSCI }\end{array}$ & $\begin{array}{l}50 \% \\
30 \%\end{array}$ & Citations Scopus & $20 \%$ \\
\hline Prestige & & & Faculty Nobel & $20 \%$ & & & $\begin{array}{l}\text { Academic Survey } \\
\text { Emplovers Survey }\end{array}$ & $\begin{array}{l}40 \% \\
10 \%\end{array}$ \\
\hline
\end{tabular}

Gambar 1. Perbandingan Metode Pemeringkatan Perguruan Tinggi dalam [7]

Pemeringkatan Webometric merupakan penilaian yang sangat penting dan informatif dari sisi akademik dan ilmiah. Sejak 2004 hasil pemeringkatan web dipublikasikan dua kali per-tahun yang menyajikan lebih dari 17.000 institusi perguruan tinggi[8]. Kehadiran web diukur dari aktifitas dan visibilitas institusi yang menjadi indikator dari pengaruh dan nama baik sebuah universitas [9]. Singkatnya, pemeringkatan ini meringkas kinerja institusi secara global serta merefleksikan komitmen sebuah institusi perguruan tinggi pada diseminasi keilmuan yang bersifat ilmiah [10].

\subsection{Webometric}

Webometric adalah peringkat institusi pendidikan tinggi yang dilakukan setiap enam bulan sekali yang bersifat independen, objektif, gratis, terbuka, multidimensi, dan berguna untuk menilai kinerja universitas di dunia. Tujuan pemeringkatan ini adalah agar pendidikan tinggi mendukung inisiatif Open Access untuk meningkatkan transfer pengetahuan ilmiah dan budaya secara signifikan yang dihasilkan oleh universitas kepada masyarakat di seluruh dunia.

Teknik Webometric didasarkan pada eksploitasi informasi yang terkandung dalam tautan atau hyperlink yang menghubungkan dokumen yang berbeda yang terdapat pada web [11]. Webometric dapat dianggap sebagai sebuah disiplin baru yang menerapkan teknik bibliometrik untuk studi kuantitatif dari web, tetapi juga disiplin yang mengembangkan konsep-konsep dan metodologinya 
sendiri. Asal usul Webometric dapat ditemukan di bidang Ilmu Informasi (information science). Istilah Webometric pertama kali diciptakan oleh Tomas Almind dan Peter Ingwersen pada tahun 1997 dan tampaknya diterima secara luas oleh komunitas penelitian bersama dengan isitilah Cybermetrics.

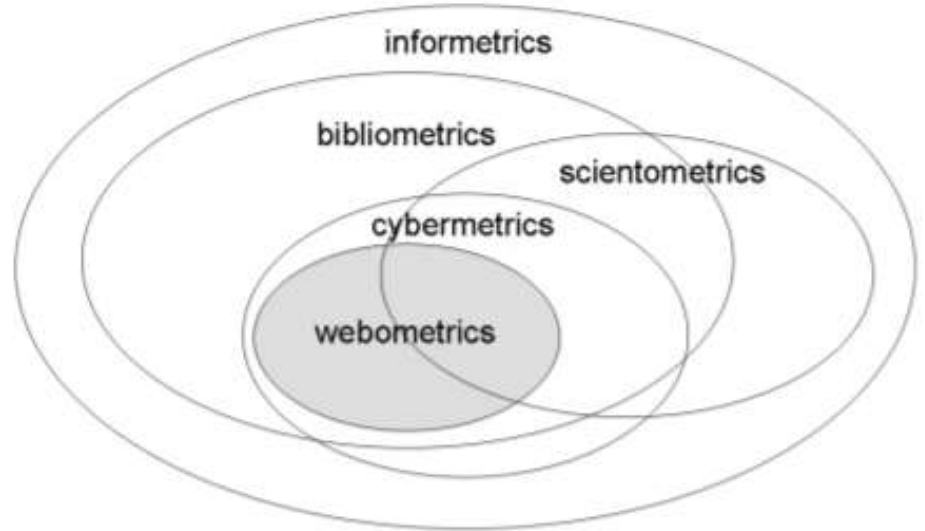

\section{Gambar 2. Cakupan konsep Webometrics (sumber: [2])}

Webometric merupakan salah satu sub-bidang dari Informetrics, yakni sebuah studi tentang aspek-aspek kuantitatif dari informasi. Dalam studi ini termasuk produksi, publikasi dan penggunaan semua bentuk informasi, terlepas dari bentuk atau asal. Dengan demikian, informetrics meliputi bidang Scientometric, yang mempelajari aspek kuantitatif ilmu; Webometric, yang mempelajari aspek-aspek kuantitatif dari World Wide Web; Cybermetric, yang mirip dengan Webometric, namun memperluas definisi yang mencakup sumber daya elektronik; Bibliometric, mempelajari aspek kuantitatif dari informasi yang dicatat.

Cybermetric lebih difokuskan pada studi fenomena internet yang bukan berbasis web, misalnya email, chat, studi newsgroup, dan lain-lain. Gambar 2 menunjukkan lokasi dan tumpang tindih dari disiplin ilmu ini dalam konteks umum Ilmu Informasi Webometric melakukan pemeringkatan terhadap lebih dari 20000 institusi perguruan tinggi diseluruh dunia. Hasil pemeringkatan dipublikasikan setiap semester pada bulan Januari dan Juli. Pada bulan Juli 2012, Webometric merubah metode pemeringkatan yang mengacu pada empat indikator penting seperti Presence $(\mathrm{P})$, Visibility (V), Transparency (T), serta Excellence (E) [2].

\subsection{Penelitian Terkait}

Selama satu dekade pembahasan Webometric terus meningkat khususnya pembahasan mengenai pengukuran dari setiap indikator dalam Webometric seperti, Presence (P), Visibility (V), Transparency (T), serta Excellence (E). Seperti dalam penelitian [12]-[16], peningkatan Webometric lebih ditekankan pada aspek Visibility dan Transparency. Pada [12], menunjukan bahwa peningkatan visibility melalui publikasi data akademis pada website universitas serta konten dan profil yang ditampilkan pada Google Scholar (GS). Selain memanfaatkan GS, [12] juga menyebutkan bahwa penggunaan sosial media yang bersifat scientific network seperti ResearchGate ataupun media sosial biasa seperti Facebook, Twitter dan Instagram terbukti efektif meningkatkan visibility universitas di Amerika Latin.

Selanjutnya [13], melakukan analisis terhadap website perpustakaan yang berada di Sri Langka untuk mengevaluasi pengaruh aspek Visibility dan Transparency. Menurut [13], perpustakaan memiliki peranan yang vital dalam menentukan nilai size dan visibility dari rich files sebuah universitas. Penelitian tersebut yang membahas pengukuran pada aspek Visibility dan Transparency menekankan perlunya repositori yang bisa dilihat oleh publik. Oleh karena itu, dalam pengembangan sebuah repositori harus memahami dan merencanakan sistem repositori dengan baik agar dapat memberikan pengaruh terhadap peningkatan visibilitas dari konten sebuah universitas. Senada dengan [13], [14] menyimpulkan bahwa repositori institusi juga memiliki peranan penting pada aspek Visibility. Selain repositori, [15] juga menunjukkan bahwa ada korelasi antara usabililty dengan tingkat visibility Webometric. Hal tersebut dibuktikan menggunakan metode Entropi dan Topsis 
dimana hasil yang dihasilkan menunjukan kesamaan dengan peringkat yang didapat pada Webometric. Dengan kata lain metode dalam [15], dapat digunakan untuk memprediksi nilai visibility.

Penelitian terkait perancangan strategi pernah dilakukan oleh [16] pada domain stikom.edu dimana peneliti mengusulkan 12 strategi baru untuk meningkatkan visibility/impact dan 17 strategi peningkatan activity. Selanjutnya, [16] juga merekomendasikan penetapan kebijakan pembagian peran kelembagaan dan sivitas akademika, rencana strategis, kolaborasi antar institusi di luar universitas (pemerintah, industri dan antar universitas) yang sistemik dan konsisten dalam mengakselerasi peningkatan 4 parameter penilaian Webometric. Namun menurut [17], perencanaan yang matang dan kerja keras seluruh sivitas akademika menjadi modal paling penting untuk menungkatkan peringkat universitas. Berdasarkan hasil [18] dalam meningkatkan peringkat Webometric di Universitas di Iran pada tahun 2016, faktor presence pada website menjadi kunci dalam pemeringkatan sehingga dengan mengoptimalkan faktor ini maka akan mendapatkan peringkat yang lebih baik. Selain itu, [18] juga menyebutkan bahwa perancangan dan pengelolaan website tanpa pengetahuan dan standarisasi akan menghadirkan permasalahan dan tidak meningkatkan peringkat. Sejalan dengan itu, [19] juga menekankan bahwa penggunaan bahasa global juga menjadi salah satu faktor penting untuk meningkatkan Webometric karena hasil pencarian mesin pencari bersifat sektoral, sehingga kemungkinan konten-konten berbahasa lokal muncul pada pencarian internasional kecil.

Metode Gap Analysis merupakan suatu metode pengukuran untuk mengetahui kesenjangan ( gap) antara kinerja suatu variabel dengan harapan pengguna terhadap variabel tersebut [21]. Dengan mengetetahui kesenjangan yang terjadi, dapat disusun langkah-langkah strategi untuk memperkecil kesenjangan yang terjadi. Metode ini dapat digunakan pada banyak bidang, misalnya [22] menggunakan metode ini untuk mengidentifikasi langkah-langkah konservasi tanaman obat di Indonesia. Selain itu, [23] juga menggunakan metode ini untuk mengembangkan model bisnis MalKita untuk meningkatkan okupansi. Metode ini digunakan untuk mengetahui strength dan weakness MalKita lalu mengembangkan model bisnis baru yang dievaluasi menggunakan metode Analytic Hierarchy Process.

\section{Metode Penelitian}

Tahapan yang digunakan dalam penyusunan penelitian ini agar meningkatkan kinerja dan rangking UNRI adalah

1. Analisis parameter Webometric

Melakukan analisis terhadap parameter yang digunakan untuk melakukan pemeringkatan Webometric. Tahapan ini penting dilakukan karena metode penilaian Webometric yang berubahubah dapat mempengaruhi perangkingan.

2. Analisis permasalahan dan performa website Unri

Aktifitas ini fokus mereview kinerja web unri.ac.id terhadap parameter Webometric yakni Presence, Impact/Visibility, Openness/Transparency dan Excellence serta menemukan permasalahan-permasalahn yang terjadi.

3. Benchmark terhadap website perguruan tinggi lainnya

Benchmark terhadapt website universitas lain bertujuan untuk menentukan goal yang harus dicapai sehingga formulasi strategi dan rekomendasi teknis dapat terukur dengan baik.

4. Analisis kesenjangan / Gap dan SWOT (Strengths, Weaknesses, Opportunities, dan Threats) Analisis ini dilakukan untuk mendeteksi kesenjangan, serta mengetahui strength dan weakness UNRI.

5. Strategi TIK dan rekomendasi teknis

Tahapan ini merupakan respon atas gap yang terjadi serta solusi terhadap permasalahanpermasalahan yang terjadi. Solusi yang didapatkan berdasarkan analisis SWOT yang dilakukan.

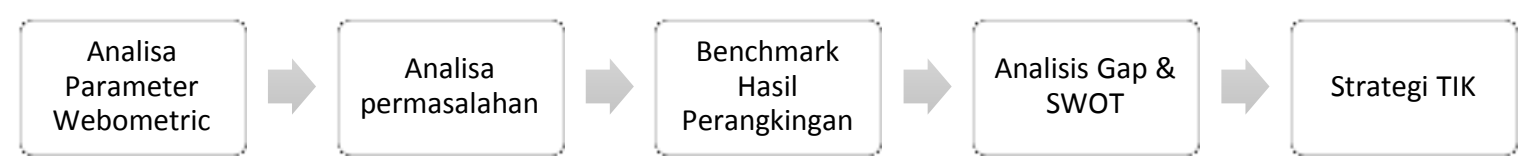

Gambar 3. Metodologi Pemeringkatan Webometric Universitas Riau 


\section{Hasil Dan Pembahasan} berikut:

Pada bagian ini akan menampilkan dan membahas hasil penelitian yang telah dilakukan sebagai

\subsection{Analisis Parameter Webometric Dan Perubahannya}

Seiring waktu, metode pemeringkatan Webometric juga mengalami perubahan untuk meningkatkan kualitas pemeringkatannya. Misalnya pada awalnya pada tahun 2008, faktor Presence atau kuantitas jumlah halaman web merupakan faktor paling penting. Namun mulai tahun 2019, terjadi perubahan bobot sehinga Presence memiliki bobot paling kecil dalam metodologi penilaian, sedangkan faktor Impact dan Excellence menjadi faktor yang lebih berpengaruh. Berdasarkan perubahan ini, Webometric mencoba menyeimbangkan antara impact dengan kuantitas atau aktifitas web. Perubahan kriteria penilaian dapat dilihat pada tabel 2 .

Tabel 2. Perubahan Bobot Penilaian Webometric

\begin{tabular}{lllll}
\hline Faktor & Sumber & $\mathbf{2 0 0 8}$ & $\mathbf{2 0 1 2}$ & $\mathbf{2 0 1 9}$ \\
\hline Presence & Google & 4 & $20 \%$ & $5 \%$ \\
\hline Visibility & Ahrefs, Majestic & 2 & $50 \%$ & $50 \%$ \\
\hline Transparancey (openness) & Google Scholar Profiles & 1 & $15 \%$ & $10 \%$ \\
\hline Excellence (or Scholar) & Scimago & 1 & $15 \%$ & $35 \%$ \\
\hline
\end{tabular}

Faktor-faktor tersebut dapat dikelompokkan menjadi dua kategori yaitu parameter aktifitas dan impact universitas, dimana kategori aktifitas terdiri atas tiga faktor yaitu Presence, Openness dan Excelence. Berdasarkan faktor Webometric tahun 2020, terdapat keseimbangan diantara kedua kategori. Faktor Presence merupakan faktor yang memiliki pengaruh sangat kecil (5\%), tetapi Presence memiliki korelasi positif terhadap faktor lainnya terhadap faktor Visibility (50\%). Visibility yang tinggi hanya dapat diraih jika kita memiliki jumlah konten yang banyak, berkualitas dan diindek dengan baik oleh mesin pencari. Selain itu, faktor Openness juga mempengaruhi Visibility karena banyak pengguna internet yang memanfaatkan hasil penelitian yang biasanya berbentuk rich konten seperi dokumen dokumen PDF, Powerpoint dan lain-lain untuk kepentingan akademis dan non akademik. Maka, untuk mendapatkan hasil yang maksimal harus memaksimalkan faktor Presence. Korelasi antara faktor dapat dilihat pada gambar 4.

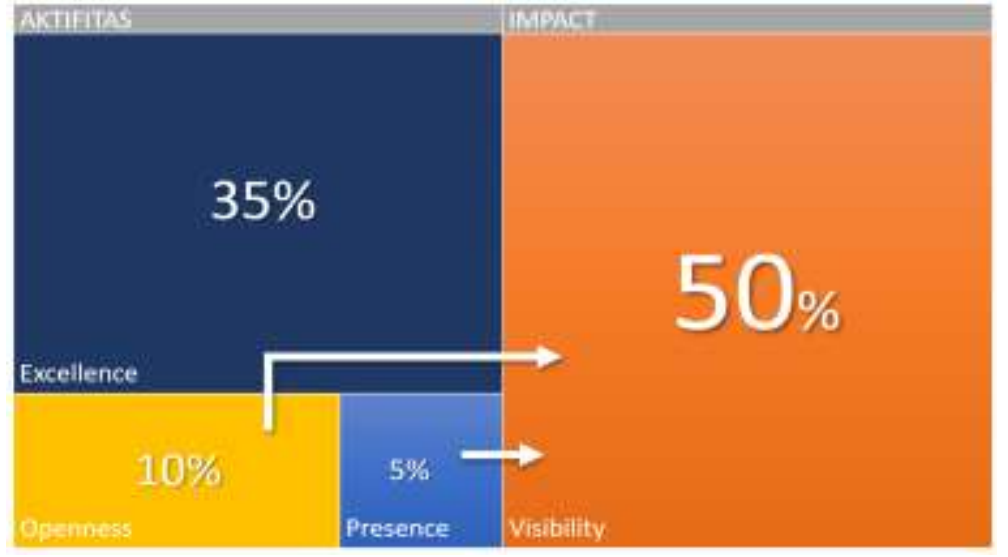

\section{Gambar 4. Kategori dan relasi faktor-faktor Webometric Edisi Juni 2020}

Selain bobot penilaian, terdapat perubahan sumber data yang digunakan, misalnya sejak tahun 2012, untuk faktor Visibility menggunakan Ahrefs, Majestic. Adapun faktor-faktor penilaian Webometric pada tahun 2020 adalah:

- Faktor Presence adalah jumlah halaman web dalam domain utama (termasuk semua subdomain dan direktori) dari universitas yang diindeks oleh mesin pencari Google. Penilaian ini 
menghitung setiap halaman web, termasuk semua dokumen dengan format yang diakui oleh Google, termasuk halaman statis dan dinamis dan selain Rich files. Namun penggunaan Google sebagai sumber data memiliki permasalahan sendiri di antaranya Google tidak mengindek semua halaman web yang ada [10, 19]; Dalam menampilkan hasil, mesin pencari melakukan pengurutan dan mengeliminasi konten yang mirip untuk menghindari informasi yang tidak penting. Hasil pencarian dapat berbeda jika melakukan pencarian dari negara atau bahasa tertentu. Oleh karena itu selain menambahkan konten, proses pengindexan dokumen pada Google juga harus diperhatikan. Pengaturan link, SEO (Search Engine Optimazion), Google Sitemap, konfigurasi dokumen robot pengarah, infrastruktur jaringan dan web server harus memadai untuk mempermudah akses crawler mesin pencari untuk menelusuri halaman web UNRI. Selain itu, perubahan nama, branding dan domain dan performa web yang mungkin berada dibawah standar (downtime dan latency yang tinggi) dapat berdampak pada peringkat Webometric karena konten tersebut berubah secara signifikan dan menurunkan faktor Presence.

- Faktor Visibility/Impact dapat dikatakan sebagai faktor kualitas konten. Faktor ini dievaluasi dengan menghitung semua tautan eksternal atau external links yang diterima oleh domain atau subdomain Universitas dari pihak ketiga. Data visibilitas dikumpulkan dari dua provider informasi yaitu Majestic SEO dan Ahrefs. Keduanya menggunakan crawler dan algoritma sendiri sehingga menghasilkan basis data yang berbeda yang digunakan bersama-sama untuk saling melengkapi atau memperbaiki kesalahan. Indikatornya adalah produk dari jumlah backlink dan jumlah domain yang berasal dari backlink tersebut, sehingga tidak hanya penting popularitas link tetapi juga kualitas dan keragaman link.

- Faktor Openness dievaluasi dengan menghitung jumlah sitasi pada peneliti di Google Scholar (GS). Webometric hanya menghitung jumlah sitasi peneliti yang terverifikasi pada email dengan domain universitas mulai dari peringkat 21 sampai 220. Peneliti peringkat 1 sampai 20 tidak dihitung karena dianggap sebagai pencilan yang tidak menggambarkan kinerja universitas. Pada faktor ini terdapat peraturan jika ditemukan akun GS yang bukan individu peneliti, misalnya akun jurnal, prodi, departemen atau kelompok riset atau ada akun GS peneliti yang mengklaim publikasi yang bukan miliknya maka institusi tersebut akan dihukum dengan nilai Openness dinilai nil.

- Faktor Excellence merupakan jumlah artikel-artikel ilmiah publikasi perguruan tinggi yang bersangkutan yang terindeks di Scimago Institution Ranking pada periode tahun 2015-2019. Jumlah artikel yang diambil adalah $10 \%$ dari artikel yang paling banyak disitasi dari 27 disiplin ilmu pada semua database. Jadi semakin banyak artikel dalam kurun waktu 5 tahun terakhir dan artikel tersebut tersebar dalam semua bidang ilmu maka semakin tinggi nilai Excellence.

\subsection{Analisis Permasalahan Dan Website Unri Saat Ini}

Website UNRI yang beralamat di www.unri.ac.id dikelola oleh UPT Teknologi Informasi dan Komunikasi (UPT TIK), namun untuk website yang berada di subdomain unri.ac.id dikelola oleh pemilik subdomain masing-masing. Misalnya website fakultas Matematika dan Ilmu Pengetahuan Alam (MIPA) dengan alamat fmipa.unri.ac.id dikelola secara mandiri oleh fakultas MIPA. Berdasarkan data spyse.com, domain unri memiliki 370 subdomain, namun banyak website dari subdomain tersebut tidak ditemukan seperti ijeba.unri.ac.id, cea.unri.ac.id, gaia.unri.ac.id, cendikia.unri.ac.id, hestia.unri.ac.id, eileithyia.unri.ac.id, trigana.unri.ac.id dan lain-lain.

Saat ini website unri.ac.id belum mengimplementasi SEO dan Internal Linking System. Hal ini terlihat dari belum terisinya meta description sebuah halaman, tidak menyertakan alternate link, media image yang digunakan tidak menggunakan keterangat teks (Alt attribute), struktur html yang tidak efisien, penggunaan tag HTML yang kurang tepat (terutama tag header), jumlah file aset yang sangat besar (rata-rata 70 dokumen), serta jumlah dokumen css dan javascipt yang banyak dan tidak di-minify. Selain itu, juga tidak menemukan sitemap yang dapat membantu mesin pencari untuk mengindek halaman-halaman di web unri.ac.id. Selanjutnya ditemukan permasalahan yang serupa pada website-website yang berada pada subdomain unri.ac.id bahkan ada website tidak mengizinkan mesin pencari untuk mengindex halaman mereka seperti faperika.unri.ac.id. Hal-hal tersebut akan mempengaruhi pencarian, jumlah halaman yang diindex dan kecepatan akses web UNRI sehingga dapat mempengaruhi nilai presence UNRI. 
Untuk website perpustakaan, ada beberapa aplikasi utama yang merupakan sumber konten terbesar di Universitas Riau di antaranya :

- Aplikasi E-Library dengan alamat http://elibrary.unri.ac.id. Aplikasi ini merupakan aplikasi ELibrary Universitas Riau yang berisi E-Book, artikel Jurnal dan artikel Ilmiah. Sampai periode Desember 2020, jumlah halaman yang di index oleh google berjumlah 877 halaman. Namun jika kita telusuri buku yang berada di E-Library dengan kata kunci kosong dengan asumsi akan menampilkan seluruh koleksi aplikasi tersebut. Berdasarkan hasil pencarian tersebut ditemukan 369 halaman dimana setiap halaman berisi 50 koleksi. Hal ini berarti, paling sedikit terdapat 18450 halaman yang tersedia namun 5\% yang diindex oleh mesin pencari.

- Aplikasi repositori dengan alamat http://repository.unri.ac.id. Aplikasi ini berisi dokumendokumen karya ilmiah di Universitas Riau dalam bentuk dokumen elektronik, namun aplikasi ini tidak digunakan lagi sejak Novermber 2019. Namun aplikasi ini telah diindex dengan baik oleh mesin pencari dan mengimplementasikan Open Standar sehingga mempermudah pencarian oleh mesin pencari.

- Aplikasi digilib dengan alamat http://digilib.unri.ac.id. aplikasi ini berisi Tugas Akhir, Skripsi, Tesis dan Disertasi Mahasiswa Universitas Riau. Sampai periode Desember 2020, jumlah halaman yang di index oleh google berjumlah 11,200 halaman. Dengan melakukan pencarian kosong, maka ditemukan 7617 halaman dengan 10 karya tulis perhalaman. Jadi halaman yang terindek oleh mesin pencari hanya $14 \%$ saja. Sebagai perbandingan, menurut [24], pada tahun 2019 jumlah wisudawan UNRI berjumlah 1814 orang dengan total alumni berjumlah 100.778. Jika dibandingkan maka ada banyak jumlah karya mahasiswa yang belum terindek dengan baik. Digilib Unri yang berisi seluruh skripsi dan karya akhir mahasiswa tidak terindek dengan baik oleh mesin pencari, sehingga selama tahun 2020 hanya menghasilkan 20 halaman. Hal ini disebabkan karena tidak semua halaman tertera di website. Untuk menemukannya pengguna harus melakukan pencarian dikotak pencarian dengan kata kunci tertentu. Mesin pencari beberja dengan cara melakukan crawling dan parsing terhadap halaman web sehingga halaman web yang tersebunyi tidak dapat tidak dapat diindek dengan baik dan sistem tidak memberikan sitemap dan mengimplementasikan standar-standar terbuka tentang berbagi konten terutama dokumen.

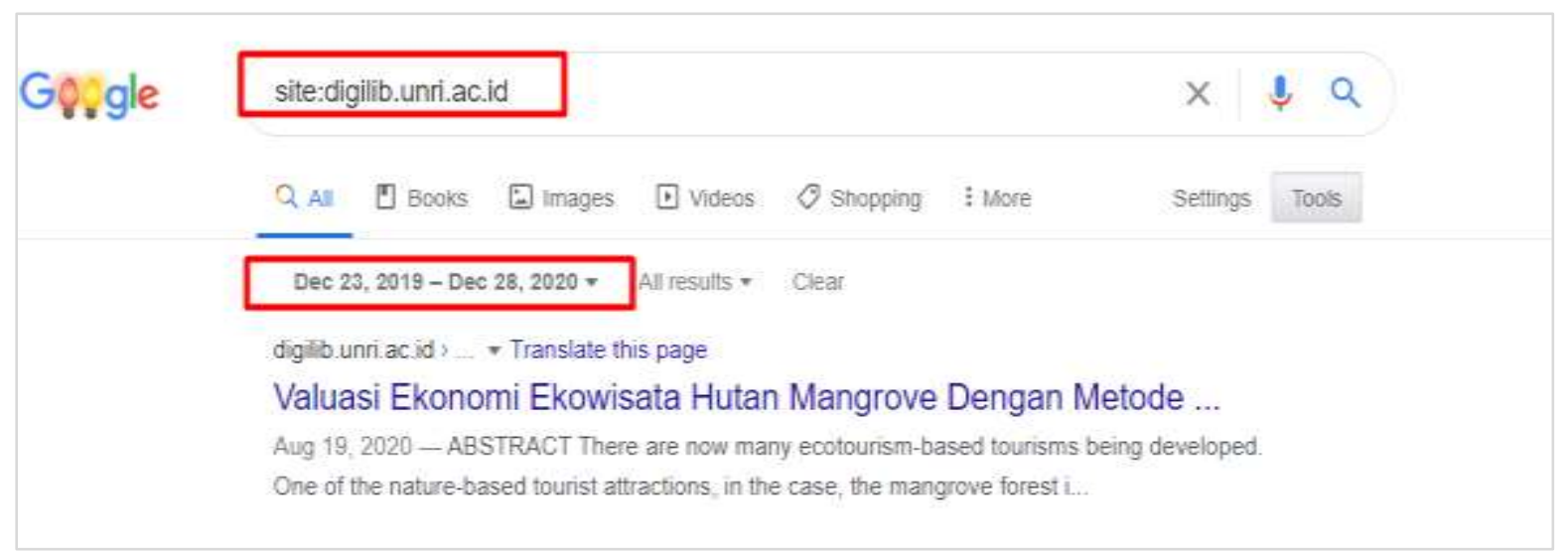

\section{Gambar 5. Hasil Pencarian di domain digilib UNRI}

Selain website, infrastruktur juga menjadi faktor yang dapat meningkatkan performa peringkat UNRI. Untuk mendapatkan hasil yang optimal, akses terhadap peladen UNRI harus bekerja dengan baik. Berdasarkan aplikasi Ubersuggest (Neilpatel.com) performa jaringan UNRI dikategorikan Poor untuk desktop dan mobile dimana untuk membuka halaman website UNRI dibutuhkan waktu sekitar 14 - 19 detik. Kategori Poor merupakan nilai paling rendah pada pengukuran tersebut. Hasil yang serupa juga didapatkan jika menggunakan aplikasi Gtmetric.com dan Google Page Speed dimana web UNRI mendapatkan nilai F dengan performa 22\% dan membutuhkan waktu 9.5 detik untuk membuka semua halaman. Hal ini tentu akan berdampak pada proses pengindekan halaman web UNRI. Web UNRI diukur pada hari minggu pukul 06.00 (gambar 6), dengan asumsi bahwa akses terhadap website minimal. 


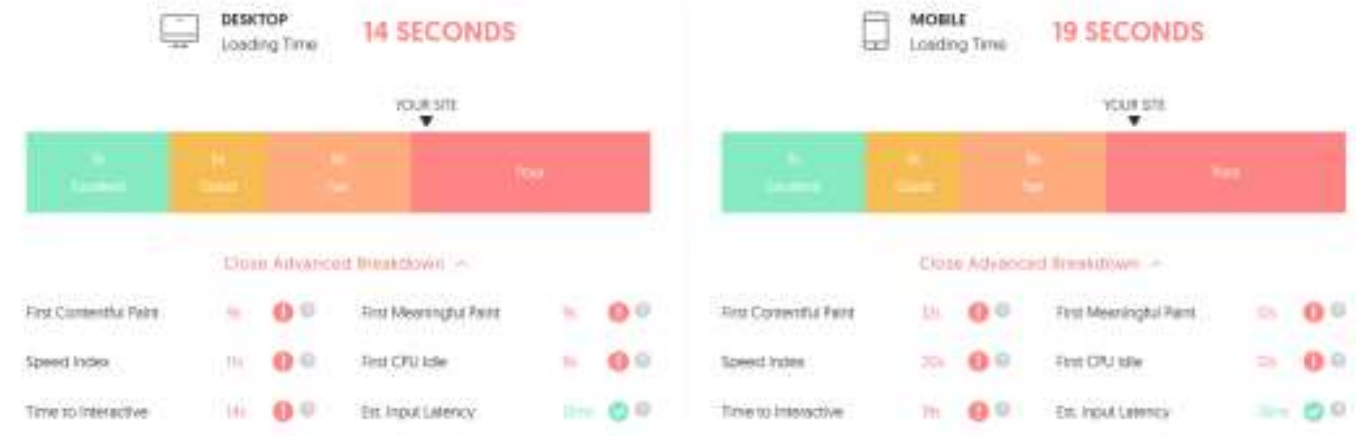

\section{Gambar 6. Response Time Server Unri.ac.id melalui Desktop dan Mobile (diakses: Minggu, 6 November 2020 pukul 06:00 WIB)}

Selain kurang optimalnya pengindexan dan infrastruktur web UNRI, beberapa web di UNRI juga mengalami SEO negatif, dimana beberapa domain telah dibobol oleh pihak tertentu lalu menyebarkan link spam pada halaman-halaman website yang berisi informasi pornografi, perjudian dan obat-obatan terlarang. Ketika web UNRI terjebak pada SEO negatif, maka akan mempengaruhi hasil pencarian pada kata kunci tertentu dan berpotensi menurunkan page rank UNRI.
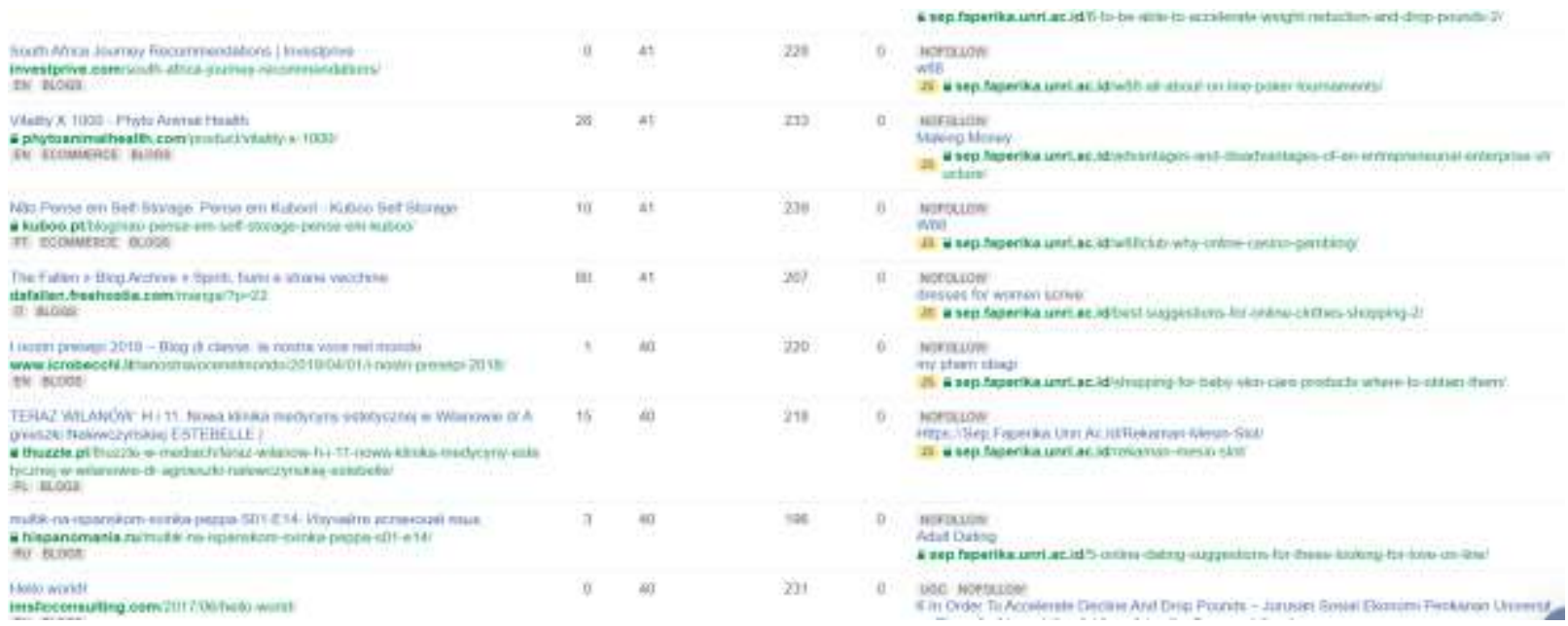

\section{Gambar 7. Daftar Halaman Negatif SEO}

Berdasarkan data penelitian pada gambar 8, menunjukkan jumlah dokumen yang diindek oleh Scopus terus meningkat setiap tahun, sebagi contoh nilai tersebut bertambah sekitar 3.5 kali dalam 5 tahun. Namun apabila diperhatikantidak terdapat peningkatan yang signifikan pada peringkat Excellence dimana pada tahun 2015 bernilai 3826 dan pada tahun 2020 bernilai 3481. Hal yang serupa juga terjadi pada faktor Openness pada tahun 2015 jumlah sitasi di GS berjumlah 5050 kemudian pada tahun 2020 meningkat menjadi 22.545. Hal tersebut juga tidak selaras dengan peringkat Openness dimana pada tahun 2015 UNRI menduduki peringkat 464 lalu turun drastis ke 5819 pada tahun 2020.

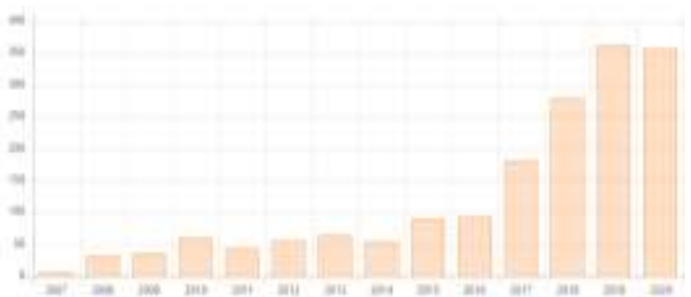

(a)

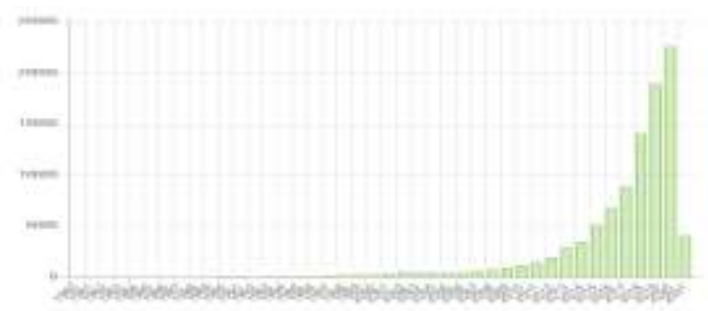

(b) 


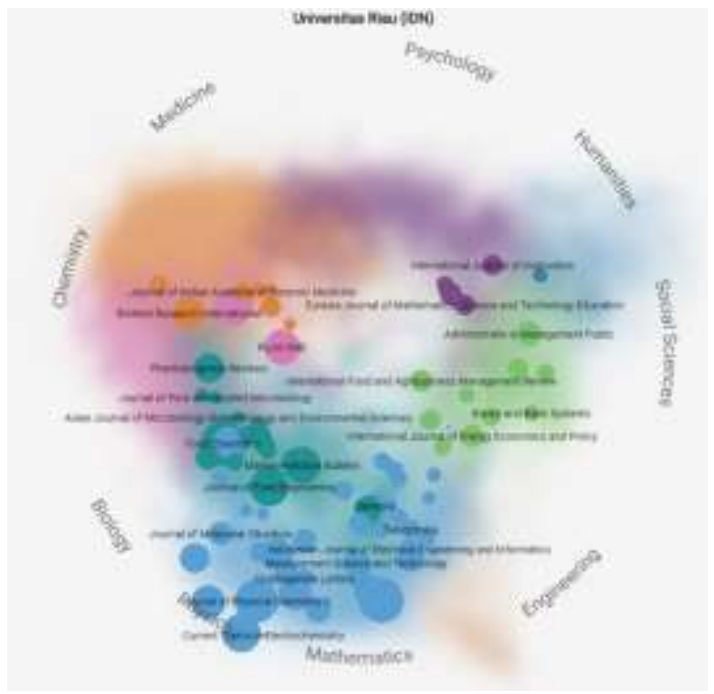

(c)

Gambar 8. (a) Grafik jumlah dokumen yang diindex oleh Scopus pertahun. (b) Jumlah sitasi dokumen pada Google Scholar pertahun. (c) Sebaran topik publikasi di Scopus

Berdasarkan hasil investigasi, permasalahan yang mempengaruhi perangkingan UNRI dari faktor Openness adalah terdapatnya akun-akun jurnal Google Scholar (GS) seperti Jurnal Komunikasi Fisika Indonesia, Melayu Laws dan lain-lain. Hal tersebut melanggar peraturan yang telah ditetapkan oleh Webometric dimana akun-akun jurnal dan departemen tidak boleh ada pada halaman GS. Akibatnya, nilai Openness UNRI menjadi sangat rendah. Selain itu, pada faktor Excellence, UNRI tidak mendapatkan nilai penuh karena pada publikasi terindek Scopus hanya didominasi oleh beberapa bidang tertentu sedangkan penilaian diambil dari seluruh bidang ilmu. Fakta tersebut ditunjukan oleh gambar 8.c dimana UNRI hanya menonjol di beberapa bidang saja.

\subsection{Benchmark Nilai Webometric}

Benchmark yang dilakukan menggunakan data peringkat Webometric 10 dan 100 teratas di Indonesia edisi Juli 2020, sedangkan untuk pencapaian target akan dibandingkan dengan tiga universitas yang berada diperingkat teratas di Indonesia yaitu Universitas Indonesia, Universitas Gajah Mada dan Universitas Sumatera Utara. Berdasarkan data statistik pada tabel 3, maka gap terbesar UNRI adalah faktor Presence dimana UNRI mendapatkan nilai sebesar 986 dan rata-rata 10 teratas adalah 343.3 dengan standar deviasi 221.83 lalu disusul faktor Impact dengan nilai 2944 dan Openness dengan nilai 5819.

Tabel 3. Statistik Komponen Penilaian Peringkat 10 Teratas di Indonesia

\begin{tabular}{lrrrrrrrr}
\hline \multirow{2}{*}{$\begin{array}{c}\text { FAKTOR } \\
\text { WEBOMETRIC }\end{array}$} & \multirow{2}{*}{$\begin{array}{c}\text { NILAI } \\
\text { UNRI }\end{array}$} & $\begin{array}{c}\text { RATA- } \\
\text { RATA }\end{array}$ & $\begin{array}{c}\text { STD } \\
\text { DEVIASI }\end{array}$ & \multicolumn{1}{c}{ MIN } & $\mathbf{2 5 \%}$ & $\mathbf{5 0 \%}$ & $\mathbf{7 5 \%}$ & MAX \\
\hline PRESENCE & 986 & 343.3 & 221.83 & 10.0 & 191.25 & 314.0 & 478.00 & 772.0 \\
\hline IMPACT & 2944 & 1041.5 & 859.41 & 465.0 & 632.50 & 765.0 & 1099.25 & 3372.0 \\
\hline OPENNESS & 5819 & 2572.9 & 2257.72 & 774.0 & 1035.25 & 1309.0 & 4818.50 & 5819.0 \\
\hline EXCELLENCE & 3481 & 2129.3 & 645.69 & 1299.0 & 1614.50 & 1985.0 & 2724.00 & 3019.0 \\
\hline
\end{tabular}

Pada faktor presence terdapat gap besar pada jumlah halaman yang diindex oleh mesin pencari. Jika dibandingkan dengan Universitas Indonesia (UI), maka jumlah halaman yang diindex oleh UI delapan kali lebih besar dari halaman yang di index oleh UNRI. 35\% halaman yang diindex oleh UI berasal dari domain lib.ui.ac.id, $28 \%$ berasal dari Repository, Scholarhub dan OCW. Hal ini menunjukkan bahwa peran perpustakaan UI sangat dominan dalam nilai peringkat Presence dan Openness. Hal yang sama juga ditemukan di Universitas Gajah Mada (UGM) dan Universitas Sumatra Utara (USU) dimana $44.5 \%$ halaman yang diindex berasal dari repositori USU. Ketiga universitas tersebut juga menerapkan konsep Open Access terhadap data penelitian yang berasal dari 
perpustakaan dan repositori, sehingga meningkatkan nilai Openness. Jika dibandingkan dengan UI maka jumlah file PDF yang terindek juga delapan kali lebih besar.

Tabel 4. Jumlah Halaman yang Diindek Oleh Google dan Jumlah Rich Content

\begin{tabular}{lcrrrr}
\hline \multirow{2}{*}{ UNIVERSITAS } & \multirow{2}{*}{ PERINGKAT } & PRESENCE & \multicolumn{3}{c}{ RICH FILES } \\
\cline { 3 - 7 } & 1 & $\begin{array}{c}\text { Jumlah } \\
\text { Halaman }\end{array}$ & PDF & PPT & DOC \\
\hline UI (ui.ac.id) & 6 & $1,240,000$ & 687,200 & 1,690 & 2,740 \\
\hline UGM (ugm.ac.id) & 8 & $1,310,000$ & 138,000 & 1,228 & 4,070 \\
\hline USU(usu.ac.id) & 35 & 703,000 & 288,000 & 124 & 971 \\
\hline UNRI(unri.ac.id) & & 149,000 & 44,300 & 135 & 614
\end{tabular}

Untuk data impact, juga terdapat perbedaan yang cukup jauh dengan UI dan UGM, tetapi dengan USU hanya terdapat sedikit perbedaan bahkan jumlah backlink UNRI lebih tinggi. Tetapi ketika dilakukan analisis mendalam, sebagian besar backlink yang berada di UNRI merupakan link yang berada di web-web yang telah diretas, sehingga sebagian besar domainnya tidak berkualitas. Selain itu, hanya $43 \%$ dari reffering domain yang dofollow domain UNRI. Hal ini sangat mempengaruhi impact dan domain rating UNRI.

Tabel 5. Perbandingan Backlink Unri.ac.id

\begin{tabular}{llll}
\hline Domain & $\begin{array}{l}\text { Domain } \\
\text { Rating }\end{array}$ & Backlink & Referring Domain \\
\hline UNRI(unri.ac.id) & 57 & $\begin{array}{l}1,418,713 \\
(95 \% \text { dofollow })\end{array}$ & $\begin{array}{l}10,710 \\
(43 \% \text { dofollow })\end{array}$ \\
\hline USU(usu.ac.id) & 66 & $\begin{array}{l}1,106,852 \\
(95 \% \text { dofollow })\end{array}$ & $\begin{array}{l}11,397 \\
(65 \% \text { dofollow })\end{array}$ \\
\hline UGM (ugm.ac.id) & 78 & $\begin{array}{l}10,574,827 \\
(89 \% \text { dofollow) }\end{array}$ & $\begin{array}{l}41,208 \\
(79 \% \text { dofollow) }\end{array}$ \\
\hline UI (ui.ac.id) & 79 & $\begin{array}{l}6,429,482 \\
(97 \% \text { dofollow })\end{array}$ & $\begin{array}{l}40,914 \\
(74 \% \text { dofollow })\end{array}$ \\
\hline
\end{tabular}

Selanjutnya, gambar 9 dan 10 menunjukan korelasi dan sebaran nilai antara faktor-faktor Webometric periode Juli 2020 pada 100 universitas di Indonesia. Berdasarkan data tersebut, rata-rata universitas di Indonesia memiliki nilai yang baik untuk Impact dan Visibility. Namun terdapat gap yang cukup dalam pada faktor openness, dimana sebagian besar universitas yang berada diperingkat 100 terbesar belum mengoptimalkan faktor ini. Sebagian besar universitas-universitas tersebut berada pada peringkat 5000-6000. 

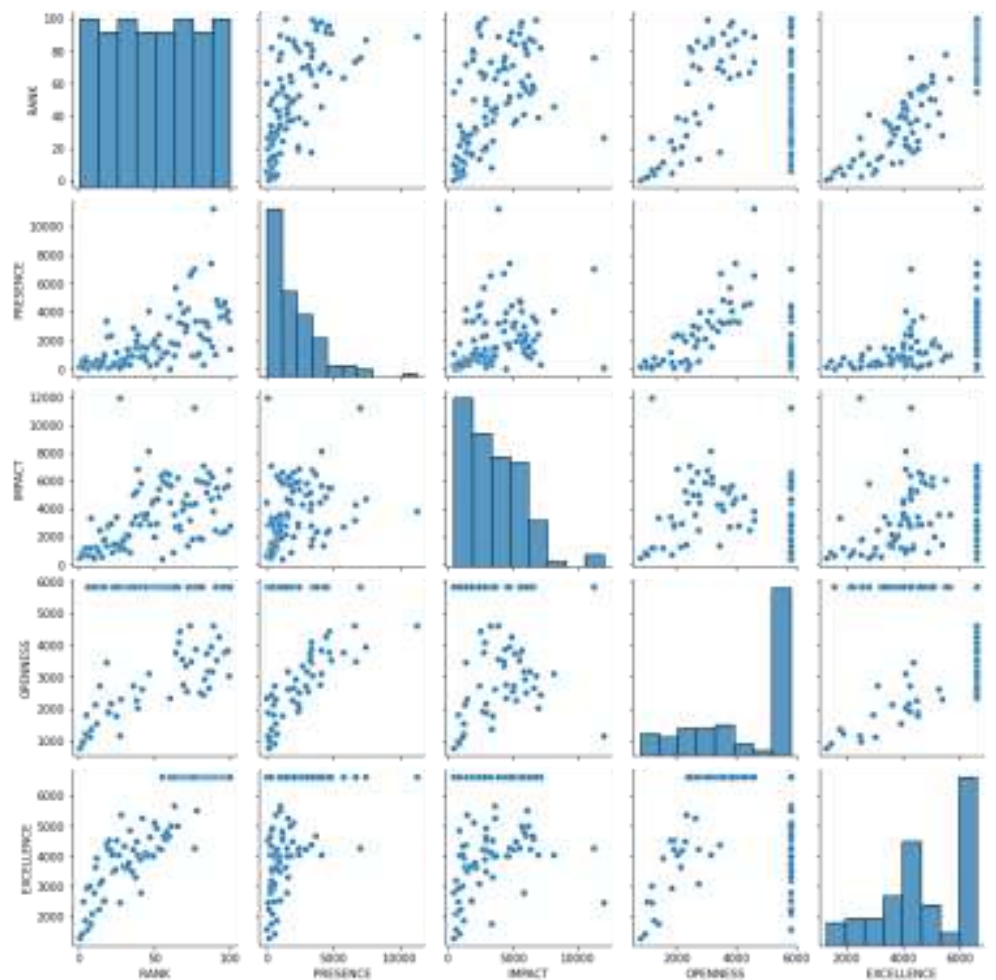

\section{Gambar 9. Grafik Pairplot Faktor-Faktor Webometric pada 100 Universitas di Indonesia Periode Juli 2020}

Pada gambar 10 jelas terlihat bahwa faktor Excelence dan Presence memiliki korelasi yang kuat dengan peringkat sebuah universitas, semakin tinggi peringkat excellence maka akan semakin tinggi peringkat Webometric. Saat ini dua faktor inilah penyumbang poin terbesar perangkingan Webometric. Selain itu, faktor Presence ini juga menunjukan korelasi positif dengan faktor Excellence.

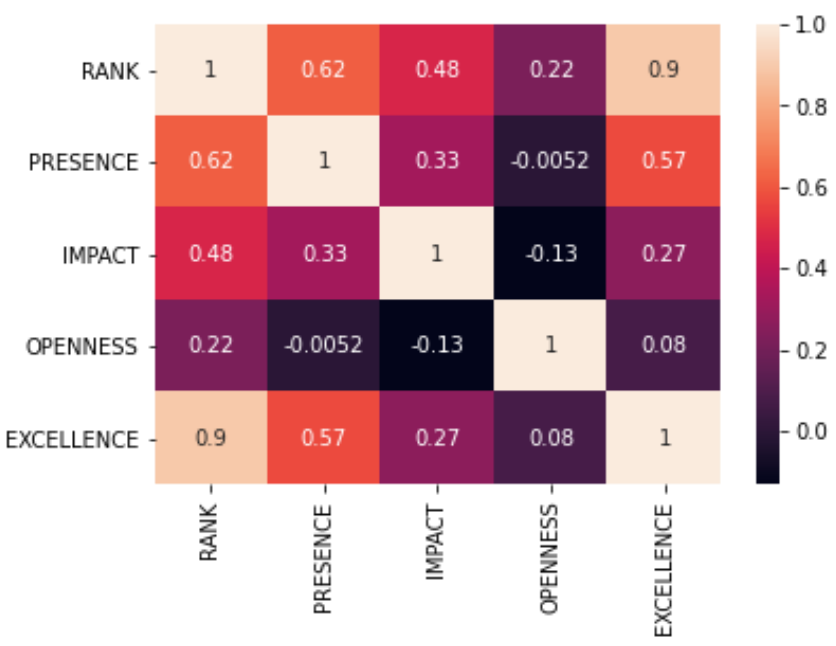

Gambar 10. Korelasi Antara Faktor Webometric pada 100 Universitas di Indonesia Periode Juli 2020 


\subsection{Analisis Gap Dan Swot}

Berdasarkan hasil analisis situasi dan benchmark maka disusunlah sebuah analisis gap. Analisis gap ini akan menentukan aksi dan strategi yang akan diambil untuk mencapai tujuan. Adapun hasil dari analisis ini ditunjukan oleh tabel 6.

Tabel 6. Hasil Analisis Gap Berdasarkan Faktor Webometric

\begin{tabular}{|c|c|c|}
\hline $\begin{array}{c}\text { Faktor } \\
\text { Webometic }\end{array}$ & Situasi Saat Ini & Situasi yang diharapkan \\
\hline PRESENCE & $\begin{array}{l}\text { - Nilai peringkat UNRI saat ini } 986 \\
\text { - Jumlah halaman yang diindek } \\
\text { oleh Google berjumlah } 149,000 \\
\text { - Belum memiliki tata kelola dan } \\
\text { strategi pengelolaan konten } \\
\text { - Website belum mengimplementasi } \\
\text { SEO } \\
\text { - Performa peladen kurang baik } \\
\text { dengan response time rata-rata } 19 \\
\text { detik }\end{array}$ & $\begin{array}{l}\text { - Nilai harapan ranking UNRI } \\
\text { adalah } 600 \\
\text { - Jumlah halaman yang diindex oleh } \\
\text { Google berjumlah } 1.000 .000 \\
\text { - Semua halaman web } \\
\text { diatur dengan tata kelola yang baik } \\
\text { dan mengimplementasi SEO } \\
\text { - Peladen UNRI mampu } \\
\text { melayani dengan response } \\
\text { time kurang dari } 10 \text { detik }\end{array}$ \\
\hline IMPACT & $\begin{array}{l}\text { - Nilai peringkat UNRI saat ini } \\
2944 \\
\text { - Domain unri.ac.id mengalami } \\
\text { SEO negatif } \\
\text { - Jumlah external backlink saat ini } \\
1,418,713 \\
\text { - Jumlah domain follower saat ini } \\
10,710\end{array}$ & $\begin{array}{l}\text { - Nilai harapan ranking UNRI } \\
\text { adalah } 1500 \\
\text { - Jumlah external backlink } \\
\text { berjumlah } 4.000 .000 \\
\text { - Jumlah domain follower } \\
20,000\end{array}$ \\
\hline OPENNESS & $\begin{array}{l}\text { - Nilai peringkat UNRI saat ini } \\
5819 \\
\text { - Sitasi GS tahun } 2020 \text { berjumlah } \\
22.545 \\
\text { - GS Akun terdapat akun jurnal dan } \\
\text { akun yang mengakuisisi artikel } \\
\text { orang lain }\end{array}$ & $\begin{array}{l}\text { - Nilai harapan ranking UNRI } \\
\text { adalah } 2000 \\
\text { - Akun GS bersih dan } \\
\text { terbaharui } \\
\text { - Sitasi tahun } 2022 \text { meningkat } \\
\text { menjadi } 50.000\end{array}$ \\
\hline EXCELLENCE & $\begin{array}{l}\text { - Nilai peringkat UNRI saat ini } \\
3481 \\
\text { - Jumlah dokumen Scopus tahun } \\
2020 \text { adalah } 357 \\
\text { - Area publikasi tidak merata }\end{array}$ & $\begin{array}{l}\text { - Nilai harapan ranking UNRI } \\
\text { adalah } 2500 \\
\text { - Pemerataan area riset } \\
\text { - Jumlah dokumen Scopus } \\
\text { tahun } 2022 \text { adalah } 500\end{array}$ \\
\hline
\end{tabular}

Selain mengindentifikasi kesenjangan yang terjadi, peneliti juga melakukan identifikasi terhadap kekuatan, kelemahan, peluang dan ancaman (SWOT - Strengths, Weaknesses, Opportunities, and Threats) yang dimiliki oleh Universitas Riau yang dihubungkan dengan rencana aksi peningkatan Webometrric. Adapun detail hasil dari Analisa SWOT disajikan pada tabel 7.

Tabel 7. Analisa SWOT Universitas Riau

\begin{tabular}{|l|ll|}
\hline \multicolumn{2}{|c|}{ Internal } \\
\hline Kekuatan (Strength) & S1) & $\begin{array}{l}\text { Jumlah mahasiswa sekitar 31725, dengan total jumlah dosen } \\
\text { sebanyak 1138 orang. (S1) }\end{array}$ \\
& S2) & Jumlah dosen di lingkungan Universitas Riau yang memiliki \\
& kualifikasi S2 berjumlah 64\% dan S3 berjumlah 36\% (S2) \\
& S3) & Tersedianya dana pengembangan TIK dan penelitian yang \\
\hline
\end{tabular}




\begin{tabular}{|c|c|c|}
\hline & $\begin{array}{l}\text { S9) } \\
\text { S10) } \\
\text { S11) } \\
\text { S12) } \\
\text { S13) }\end{array}$ & $\begin{array}{l}\text { cukup (minimal 15\% dari PNBP) (S3) } \\
\text { Peraturan tentang remunerasi dimana dosen harus } \\
\text { mengunggah dokumen berupa RP/RPS dan bahan ajar untuk } \\
\text { verifikasi remunerasi. } \\
\text { Dosen dan mahasiswa telah terbiasa menggunakan E- } \\
\text { Learning } \\
\text { Terlaksananya kegiatan KKN Terintegrasi dengan } \\
\text { Pengabdian Kepada Masyarakat yang berkualitas secara } \\
\text { berkesinambungan dengan luaran berupa Monograf Desa, } \\
\text { Profil desa dan lain-lain } \\
\text { Adanya tenaga ahli yang mempunyai kesesuaian kebutuhan } \\
\text { dengan kompetensi tenaga penelitian. } \\
\text { Adanya Pusat Studi HAKI yang melaksanakan pengurusan } \\
\text { hak paten dari penelitian dosen dan mahasiswa Universitas } \\
\text { Riau. } \\
\text { Adanya publikasi ilmiah internasional terindeks, jurnal } \\
\text { nasional terakreditasi, prosiding } \\
\text { internasional terindeks, prosiding nasional dan jurnal yang } \\
\text { diterbitkan oleh UNRI. } \\
\text { Tersedianya information and communiacation technology } \\
\text { (ICT) berkualitas. } \\
\text { Jumlah kerjasama dengan pihak ke-3 (Swasta, BUMN dan } \\
\text { Pemerintah Daerah) cukup tinggi. } \\
\text { Setiap mahasiswa yang lulus wajib membuat Karya Akhir } \\
\text { atau Skripsi, Thesis dan Disertasi serta jurnal mahasiswa. }\end{array}$ \\
\hline Kelemahan (Weakness) & $\begin{array}{l}\text { W2) } \\
\text { W3) } \\
\text { W4) } \\
\text { W5) } \\
\text { W6) }\end{array}$ & $\begin{array}{l}\text { Belum ada kebijakan untuk menggunakan konten-konten } \\
\text { hasil pembelajaran, KUKERTA (Kuliah Kerja Nyata), } \\
\text { magang untuk dipublikasikan secara online dan dapat diakses } \\
\text { oleh publik. } \\
\text { Kerjasama yang dilakukan UNRI hanya sebatas kegiatan } \\
\text { luring (luar jaringan) } \\
\text { Belum adanya penanggung jawab yang khusus mengelola } \\
\text { perangkingan universitas. } \\
\text { Kurangnya kesadaran untuk menggunakan aplikasi berbasis } \\
\text { Open Standar } \\
\text { Rendahnya kesadaran dan kemauan dosen untuk mendukung } \\
\text { gerakan Open Access } \\
\text { Belum optimalnya kerja sama dari pusat-pusat studi hal ini } \\
\text { dapat dilihat sedikitnya penelitian kerjasama antar pusat } \\
\text { penelitian. } \\
\text { Belum lengkapnya sarana dan prasarana penelitian. } \\
\text { Kurangnya minat dosen terlibat dalam penelitian. } \\
\text { Jumlah dosen yang terlibat penelitian kompetitif nasional } \\
\text { relatif rendah dibanding dengan jumlah dosen yang ada. }\end{array}$ \\
\hline \multicolumn{3}{|r|}{ Eksternal } \\
\hline Peluang (Opportunities) & $\begin{array}{l}\text { O1) } \\
\text { O2) }\end{array}$ & $\begin{array}{l}\text { Meningkatkan konten digital UNRI kegiatan pendidikan, } \\
\text { KUKERTA, penelitian, pengabdian dan sebagainya. } \\
\text { Meningkatkan kerjasama luar jaringan (luring) menjadi } \\
\text { kerjasama dalam jaringan (daring) dengan Pemerintah } \\
\text { Daerah, instansi swasta, maupun Universitas dalam dan luar } \\
\text { negeri. } \\
\text { Terbukanya peluang kerjasama penelitian dengan instansi } \\
\text { pemerintah, BUMN, maupun swasta. } \\
\text { Banyaknya dana penelitian yang tersedia dari berbagai }\end{array}$ \\
\hline
\end{tabular}




\begin{tabular}{|l|l|l|}
\hline & O5) $\begin{array}{l}\text { sumber. } \\
\text { Adanya program peningkatan kompetensi akademik bagi } \\
\text { dosen yang diadakan oleh UNRI. } \\
\text { Adanya komitmen Pemerintah Daerah untuk mendukung } \\
\text { pengadaan sarana dan prasarana untuk pengembangan } \\
\text { UNRI. }\end{array}$ \\
\hline Oncaman (Threat) & T1) $\begin{array}{l}\text { Kualitas penelitian perguruan tinggi negeri dan swasta selain } \\
\text { Universitas Riau yang semakin baik } \\
\text { Persaingan dalam meraih dana penelitian serta hasil } \\
\text { penelitian yang dipatenkan. }\end{array}$ \\
\hline
\end{tabular}

\subsection{Strategi Peningkatan Peringkat Webometric}

Berdasakan analisis permasalahan dan perbandingan terhadap universitas-universitas yang berada di peringkat 10 dan 100 teratas Webometric di Indonesia maka dirumuskanlah strategi yang akan dilakukan untuk untuk meningkatkan Webometric UNRI. Strategi-strategi tersebut harus dilakukan secara berkesinambungan dan didukung oleh semua pihak. Strategi peningkatan Webometric UNRI fokus kepada tiga pilar utama yang didukung oleh kebijakan universitas. Tujuannya adalah untuk meningkatkan peringkat Webometric UNRI. Adapun pilar-pilar utama yang menjadi strategi untuk peningkatan Webometric UNRI adalah adalah pengembangan konten dan website, pengembangan interlink dan penguatan publikasi riset. Gambar 11 menunjukkan komponen strategi peningkatan Webometric UNRI.

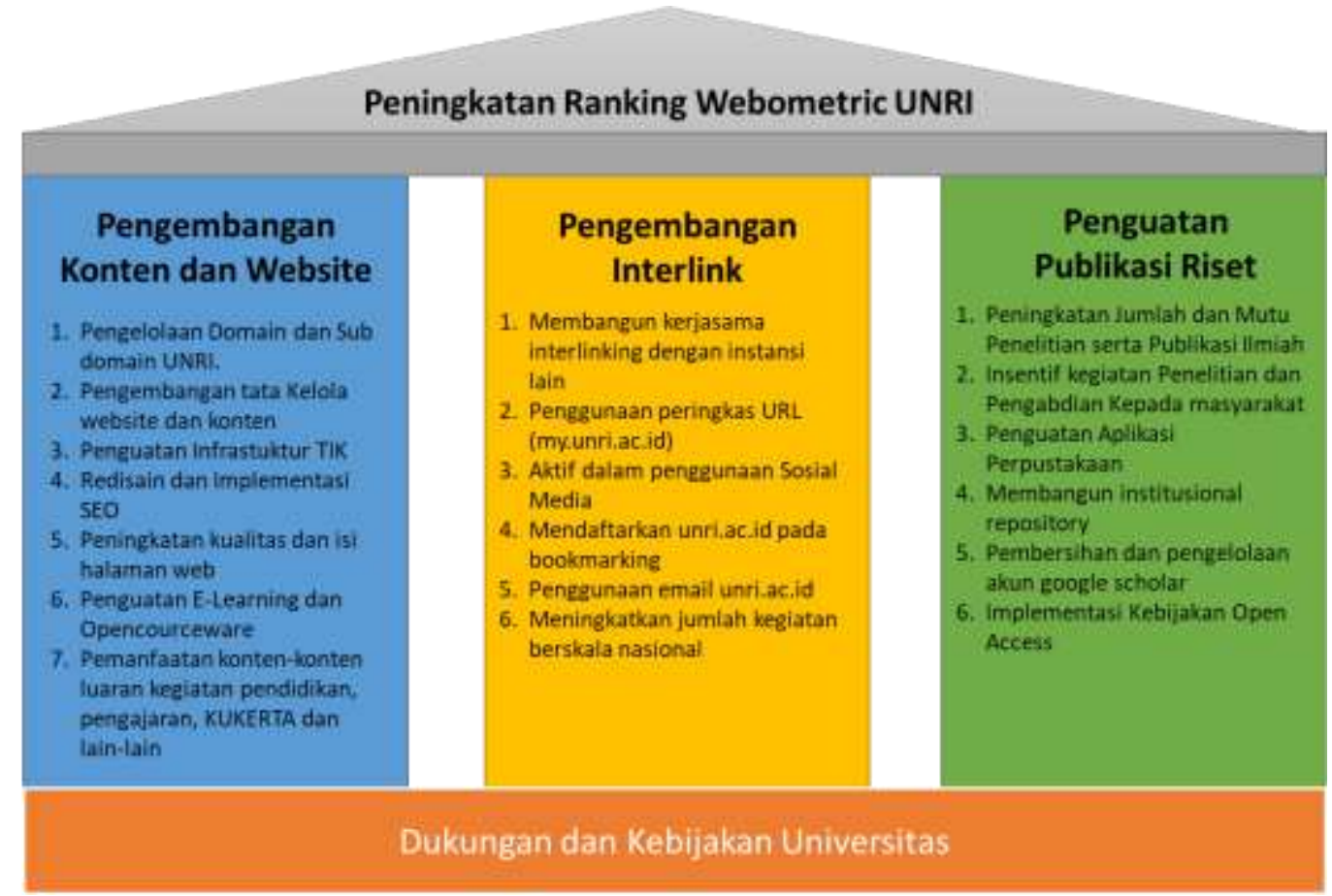

\section{Gambar 11. Komponen Strategi Peningkatan Peringkat Webometric UNRI}

Pada strategi tersebut, dukungan pimpinan UNRI dan diimplementasikan dalam bentuk kebijakan universitas memiliki peranan yang paling vital karena strategi-strategi yang akan diimplementasi bersifat lintas unit kerja didalam UNRI. Sehingga dengan adanya dukungan dan kebijakan pimpinan tersebut maka pimpinan pada level fakultas dan unit kerja memiliki kejelasan dan status hukum yang jelas dalam implementasinya. Selain itu perlu juga ditanamkan bahwa peningkatan peringkat Webometric ini merupakan tanggung jawab bersama mulai dari pimpinan, dosen, karyawan dan mahasiswa.

Adapun strategi-strategi dan langkah-langkah peningkatan peringkat Webometric UNRI adalah : 


\subsubsection{Strategi Pengembangan Konten dan Website}

Strategi ini fokus kepada jumlah dan kualitas konten pada halaman website UNRI. Strategi ini dapat meningkatkan faktor presence UNRI. Dengan meningkatnya faktor presence sebenarnya juga meningkatkan peluang meningkatkan faktor impact. Adapun langkah teknis yang dilakukan pada strategi ini adalah:

\section{A1. Pengelolaan domain dan subdomain UNRI}

Saat ini, UNRI memiliki domain utama yaitu www.unri.ac.id. Setiap besar unit kerja dan fakultas di UNRI telah memiliki website dengan subdomain unri.ac.id. Namun demikian masih terdapat beberapa bagian menggunakan domain selain unri.ac.id dan banyak subdomain unri.ac.id yang tidak aktif dan dikelola dengan baik. Selain itu, perlu adanya kebijakan terkait dengan penamaan sub domain di lingkungan sehingga penamaan subdomain terstandarisasi dengan baik. Semua web institusi harus menggunakan domain unri.ac.id serta menggunakan akronim yang terkenal. Subdomain juga dapat menggunakan kata-kata yang umum dan menarik. Hindari perubahan nama domain, mirror domain dan gunakan layanan hosting yang memiliki akses dan kecepatan yang baik.

\section{A2. Pengembangan tata kelola website dan konten UNRI}

Pengembangan tata kelola website dan konten yang mengintegrasikan seluruh aktifitas akademik dan akademik UNRI. Dengan adanya tata kelola yang baik maka dapat melibatkan seluruh stakeholder yang ada di UNRI dalam proses content generator. Selanjutnya untuk pengembangan konten/isi dilakukan secara profesional didukung tim penulis dan designer, sehingga secara isi dan kualita dapat terjaga. Penggunakan dua bahasa diwajibkan, terutama bahasa Inggris karena audiens web benar-benar global. Versi bahasa, terutama dalam bahasa Inggris, wajib tidak hanya untuk halaman utama, tetapi untuk bagian tertentu dan khususnya dari dokumen ilmiah. Dalam penyajian konten, memperbanyak format rich file dan mudah di baca seperti Adobe Acrobat pdf atau MS Word memungkinkan distribusi dokumen yang lebih baik. Hindari format yang tidak mudah dibaca oleh mesin seperti dokumen SK yang dipindai sehingga menjadi gambar. Hal tersebut kurang baik karena mesin pencari tidak dapat membaca konten dokumen tersebut sehingga tidak memberikan impact yang baik. Sistem penulisan konten ini dapat didistribusi pada beberapa level misalnya, pusat komputer dapat bertanggung jawab atas pedoman desain dan informasi kelembagaan, sedangkan Perpustakaan, Unit Kerja, Dosen dan layanan serupa dapat bertanggung jawab dalam pengembangan konten. Agar tidak terjadi kesenjangan, maka standarisasi isi situs dan konten perlu diterapkan seperti penggunaan judul-judul yang bermakna, pemilihan kata kunci dan deskriptif dapat meningkatkan visibilitas halaman.

\section{A3. Penguatan Infrastruktur TIK}

Penguatan infrastruktur jaringan dan peladen yang menghubungkan pengguna, mesin pencari dan peladen perlu ditingkatkan untuk meningkatkan peringkat Webometric UNRI. Penguatan jaringan ini meliputi jaringan internal dan external dapat dilakukan melalu analisis kebutuhan aplikasi yang ada di UNRI. Selain itu, pengembangan Data Recovery Center sangat diperlukan untuk mencegah resikoresiko yang diakibatkan oleh bencana (disaster) seperti kebakaran, gempa bumi, banjir, tsunami dll. Selain itu perlu juga penyusunan rencana pemulihan bencana (Disaster Recovery Plan/DRP) dengan dukungan DRC (Disaster Recovery Center) sebagai tempat/area penyimpanan serta pengolahan data dan informasi pada saat terjadinya bencana yang mengakibatkan Data Center yang ada mengalami gangguan sementara, sebagian atau bahkan rusak total sehingga memerlukan waktu yang lama untuk melakukan pemulihan.

\section{A4. Redesain dan Perbaikan SEO Website UNRI}

SEO (Search Engine Optimization) adalah serangkaian proses yang dilakukan secara sistematis yang bertujuan untuk meningkatkan volume dan kualitas trafik kunjungan melalui mesin pencari menuju situs web UNRI dengan memanfaatkan mekanisme kerja atau algoritma mesin pencari tersebut. Tujuannya adalah agar mesin pencari menempatkan sebuah situs web UNRI pada posisi teratas, atau setidaknya halaman pertama hasil pencarian berdasarkan kata kunci tertentu yang ditargetkan. Secara logis, situs web yang menempati posisi teratas pada hasil pencarian memiliki peluang lebih besar untuk mendapatkan pengunjung sehingga peluang untuk meningkatkan impact 
lebih besar. Mendesain web ramah pengguna dan mesin pencari serta menghindari menu navigasi rumit berdasarkan Flash, Java atau JavaScript yang dapat memblokir akses mesin pencari/robot. Direktori yang terstruktur rumit dalam atau interlinking yang kompleks juga dapat memblokir robot.

Saat ini belum ada sebuah sitemap yang berisi seluruh halaman pada web UNRI. Sitemap adalah daftar berisi semua halaman website yang dapat diakses oleh pengunjung dan mesin pencari. Manfaat sitemap adalah membantu mesin pencari agar lebih mudah ditemukan dan lebih cepat terindeks. Sitemap juga akan memberitahu mesin pencari ketika terjadi perubahan struktur di website.

Selain itu dengan menambahkan domain unri.ac.id serta subdomainnya pada Google Search Console (sebelumnya dikenal sebagai Google Webmaster Tools) dapat memonitor bagaimana kinerja website di ranah organik Google. Google Search Console memungkinkan mengetahui domain yang memberikan link ke website Anda (referring domain), kinerja website di perangkat mobile, hingga analisis halaman website dengan trafik tertinggi.

\section{A5. Peningkatan kualitas dan isi pada halaman web}

Peningkatan kualitas dan isi pada halaman web bertujuan agar meningkatkan jumlah pengunjung dan backlink pada halaman web UNRI. Selain itu konten-konten informasi berupa gambar dikonversi menjadi dokumen teks dan tersedia dalam bahasa internasional. Penggunaan bahasa internasional pada halaman web UNRI membantu meningkatkan ukuran dan kualitas halaman web. Metode penghitungan presesence menggunakan mesin pencari Google dimana ketidakstabilan hasil pencarian pada search engine sangat tinggi. Salah saktor penyebabnya adalah lokasi berbeda. Sebagai contoh pengguna Indonesia akan diarahk ke google.co.id untuk melakukan pencarian dan prioritas halaman yang ditampilkan adalah halaman Bahasa Indonesia. Namun sehingga ketika pengguna menggunakan google.com maka hasil dalam Bahasa Inggris lebih diutamakan. Hal ini membuat perbedaan hasil pencarian karena lokasi dan bahasa yang digunakan. Oleh karena itu maka dengan menggunakan bahasa intenasional maka dapat mengurangi anomali ini.

\section{A6. Aktif dalam penggunaan E-Learning dan Open Courceware}

Pada masa Covid-19 merupakan era emas E-Learning dimana semua perkulihaan dilakukan secara daring. Kondisi ini dapat dimanfaatkan untuk peningkatan konten melalui aplikasi E-Learning dan Open Courceware. Open courseware adalah sebuah konsep pendidikan yang revolusioner yang mengizinkan semua orang untuk mendapatkan atau mengakses perkuliahan secara gratis melalui jaringan. Aplikasi ini sangat membantu visibility UNRI di Indonesia dan di dunia karena kontenkonten pembelajaran tersebut akan selalu dibagikan ke website-website maupun di sosial media.

\section{A7. Pemanfaatan konten-konten luaran kegiatan pendidikan, pengajaran, KUKERTA dan lain-lain}

Kegiatan pendidikan, pengajaran, KUKERTA dan lain-lain merupakan konten yang sangat berharga dan jumlahnya terus bertambah setiap hari. Langkah ini merupakan langkah yang paling efektif untuk meningkatkan volume halaman atau konten UNRI.

\subsubsection{Strategi Pengembangan Interlink}

Pengembangan interlink merupakan strategi yang relatif mudah dilakukan dan memiliki impact yang cukup besar jika dibandingkan dengan strategi lainnya. Strategi ini mempengaruhi faktor visibility yang bernilai 50\%. Adapun langkah teknis yang dapat dilakukan adalah :

\section{B1. Membangun kerjasama interlinking}

Dalam membangun kerjasama dengan instansi luar baik pemerintah, industri maupun universitas tidak hanya dilakukan pada kegiatan offline tetapi juga melakui online dengan melakukan interkoneksi link website UNRI. Kegiatan ini dapat meningkatkan jumlah external link dan page rank UNRI. Sebagai contoh pemerintah daerah memberikan tautan keberadaan universitas di wilayahnya melalui halaman web atau pihak industri menautkan url publikasi teknologi yang telah mereka adopsi.

\section{B2. Penggunaan Peringkas URL my.unri.ac.id}

My UNRI merupakan aplikasi peringkas URL. Aplikasi ini bertujuan meringkas URL yang panjang sehingga lebih mudah digunakan. Selain itu dengan menggunakan aplikasi ini pengguna telah 
mengkonversi link external menjadi link UNRI. Sebagai ilustrasi, sejak masa COVID-19, frekuensi webminar, dan perkuliahan melalui platform Zoom atau Gmeet meningkat drastis. Biasanya para pelaksana kegiatan akan membagikan URL untuk mengikuti kegiatan tersebut. URL-URL tersebut di konversi menjadi URL UNRI, sehingga ketika dibagikan ke platform media sosial atau halaman web lainnya menjadi backlink untuk UNRI sehingga menambah nilai Visibility UNRI

B3. Aktif dalam pemanfaatan media sosial

Media sosial merupakan flatform yang paling efektif untuk meningkatkan engagement kepada pengguna atau stakeholder Universitas. Ketika engagement di akun sosmed Universitas bagus atau biasa disebut memiliki social signal yang baik, maka mesin pencari dapat melihat dan menganalisis aktifitas tersebut. Social signal ini adalah salah satu faktor yang sangat penting di era SEO moderen ini. Semakin baik social signal, maka popularitas website semakin baik di mesin pencari sehingga peluang untuk meningkatkan visibility menjadi lebih besar.

Selain itu beberapa media sosial yang bersifat kontribusi dokumen atau tulisan seperti wikipedia, slideshare, github dan lain-lain memiliki domain rating yang sangat tinggi. Hal ini merupakan peluang untuk mendapatkan banyak backlink berkualitas. Sebagai contoh wikipedia, dimana pengguna dapat membuat sebuah artikel lalu melakukan sitasi kehalaman web tertentu. Hal ini jika dimanfaatkan dengan baik oleh UNRI maka dapat meningkatkan impact secara signifikan. Saat ini UNRI hanya memiliki satu backlink dari Wikipedia sehingga peluang masih terbuka lebar. Beberapa kebijakan terkait pemanfaatan sosial media telah dilakukan seperti menjadikan halaman wikipedia desa tujuan Kukerta (Kerja Kuliah Nyata) menjadi salah satu luaran wajib kegiatan Kukerta. Kegiatan ini selain bermanfaat untuk desa tujuan juga memberikan external backlink kepada UNRI.

Selain itu kebijakan untuk memperbaharui media sosial dibidang akademis, deposit dan blogging seperti Google Scholar, Research Gate, Academia dan lain-lain juga dapat meningkatkan visibility dan Openness UNRI. Gambar 12 menunjukkan beberapa media sosial yang dapat digunakan untuk peningkatan Webometric berdasarkan kategori.

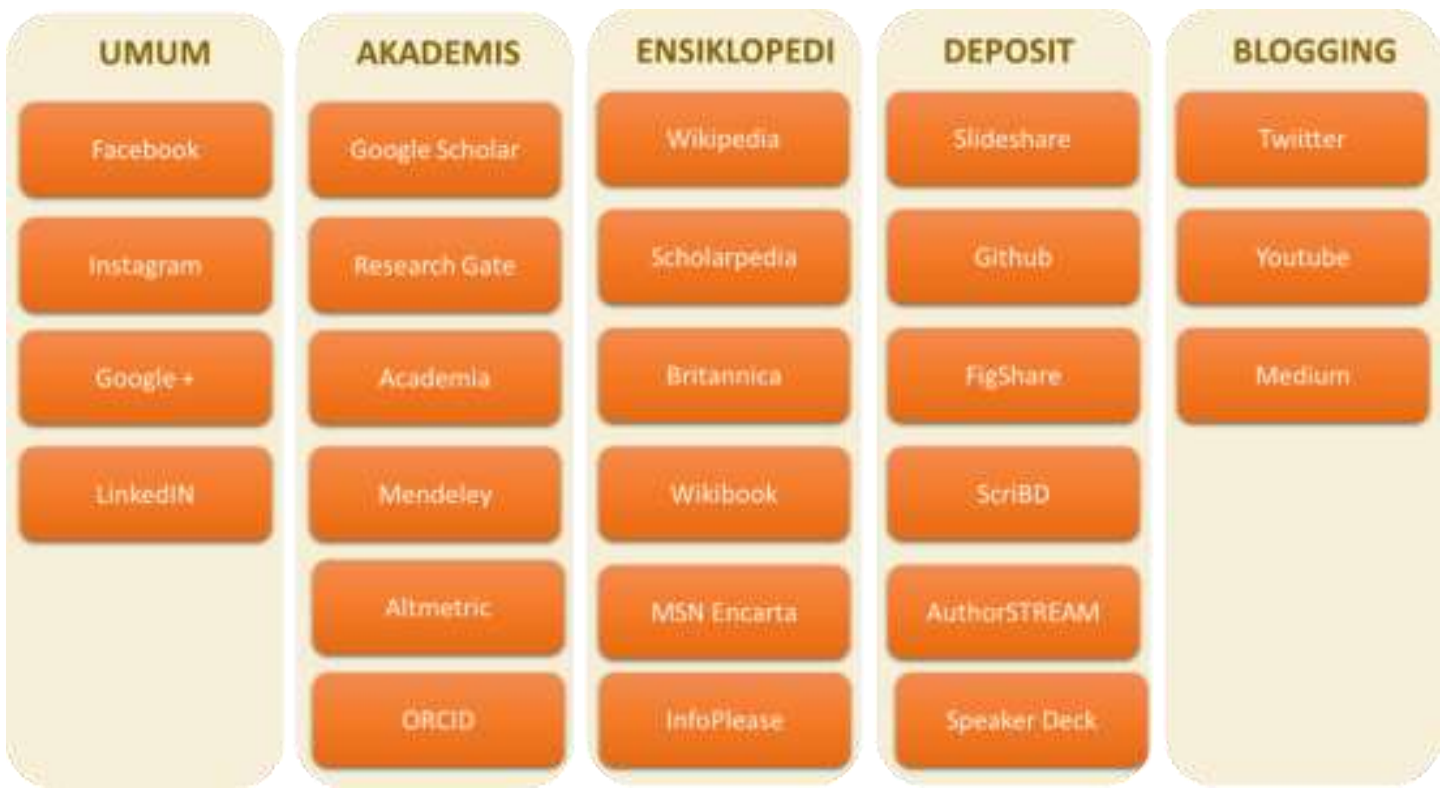

\section{Gambar 12. Daftar Sosial Media yang Dapat Dimanfaatkan untuk Peningkatan Webometric}

B4. Mendaftarkan web unri ke website-website repository dan bookmarking

Mendaftarkan domain unri ke website repository dan bookmarking merupakan sebuah langkah awal untuk meningkatkan Visibility. Bergabungnya UNRI dalam website-website repository seperti OpenDOAR, Sherpa, ROAR, RSP dan lain-lain menguntungkan UNRI karena selain memberikan external backlink, juga dapat meningkatkan Openness. Sebagai contoh OpenDOAR adalah sebuah direktori yang menyimpan alamat Open Access Repositories dimana pengguna dapat mencari dan 
menemukan konten-konten pada direktori itu. Dengan terdaftar di OpenDOAR maka akan meningkatkan peluang untuk disitasi menambah external backlink.

\section{B5. Penggunaan email unri.ac.id}

Peneliti di lingkungan UNRI dianjurkan untuk menggunakan email UNRI dengan format email nama@lecturer.unri.ac.id. Dengan email ini, dosen dianjurkan segera mendaftarkan diri pada Google Scholar sehingga dapat terverifikasi sebagai peneliti dilingkungan UNRI. Selain itu, pada pendaftaran GS dan sistem lainnya dosen dihimbau selalu menggunakan nama institusi lengkap dan baku dalam publikasi ilmiah. Nama institusi lengkap ditulis "Universitas Riau" tidak diperkenankan menuliskan nama institusi dengan singkatan UNRI atau Unri maupun menggunakan alternatif bahasa Inggris seperti Riau University atau University of Riau.

B6. Meningkatkan jumlah kegiatan berskala nasional maupun internasional

Melakukan kegiatan berskala nasional maupun internasional dapat diartikan sebagai upaya untuk menarik perhatian masyarakat terhadap UNRI. Kegiatan-kegiatan tersebut dapat berupa kegiatan daring ataupun luring. Kegiatan-kegiatan ini dapat meningkatkan backlink UNRI, apalagi jika ada banyak pihak eksternal yang membantu mempublikasikan kegiatan ini.

\subsubsection{Strategi Penguatan Publikasi Riset}

Penguatan publiksi dan riset ini mempengaruhi faktor Openness dan Excellence. Adapun langkah-langkah teknis yang dapat dilakukan di antaranya :

\section{C1. Peningkatan Jumlah dan Mutu Penelitian serta Publikasi Ilmiah}

Strategi ini telah dilakukan oleh LPPM UNRI karena untuk urusan penelitian dan publikasi ilmiah merupakan tanggung jawab dari LPPM UNRI. Adapun program-program yang telah dijalankan adalah Program Peningkatan Jumlah dan Mutu Penelitian, Program Pengembangan Jaringan Kerjasama Penelitian, Program Peningkatan Jumlah dan Mutu Publikasi Ilmiah dan Program Pengembangan Teknologi Tepat Guna dan Penerapannya bagi Masyarakat.

\section{C2. Insentif kegiatan Penelitian dan Pengabdian Kepada masyarakat}

Kebijakan untuk meningkatkan jumlah luaran penelitian dan pengabdian kepada masyarakat dimana setiap luaran berupa artikel, pengusulan insentif HKI dan buku Ajar / Teks diberikan insentif sesuai dengan aturan yang dibuat oleh Lembaga Penelitian dan Pengabdian kepada Masyarakat (LPPM) UNRI. Kegiatan ini dikelola oleh sebuah sistem informasi (insentifppm.unri.ac.id) dimana dosen yang mengusulkan insentif harus mengumpulkan luaran tersebut lalu sistem melakukan dokumentasi dan publikasi di aplikasi direktori peneliti (peneliti.unri.ac.id).

\section{C3. Penguatan Aplikasi Perpustakaan, Repositori dan Sistem Informasi pendukung lainnya}

Aplikasi perpustakaan dan repositori merupakan salah satu peralatan yang digunakan untuk melakukan diseminari hasil riset. Dapat dikatakan aplikasi-aplikasi ini merupakan tulang punggung dari peringkat Webometric UNRI oleh karena itu perlu konsistensi dalam mengupdate aplikasi ini dan aplikasi-aplikasi dapat diindex dengan baik. Salah satu cara agar dapat diindex dengan baik adalah dengan menggunakanan sitemap atau mengimplementasi protokol-protokol Open Standar dalam berbagi data sebagai contoh Open Archive Initiative Protocol for Metadata Harvesting (OAI-PMH). OAI-PMH adalah sebuah mekanisme untuk mengumpulkan catatan yang berisi metadata dari repositori. OAI-PMH memudahkan penyedia data untuk menyajikan metadata, berdasarkan standar HTTP (Hypertext Transport Protocol) dan XML (Extensible Markup Language). Metadata yang diambil dapat memungkinkan dalam format apapun sesuai yang disepakati dalam suatu forum penyedia data dan penyedia layanan, sesuai dengan Dublin Core (DC) yang telah ditentukan untuk menyediakan level dasar interoperabilitas. Dengan demikian, metadata dari berbagai sumber bisa dikumpulkan dalam satu database dan layanan dapat diberikan berdasarkan data yang sudah terpusat.

Selain itu dapat dikembangkan pula aplikasi-aplikasi lainnya untuk menambah konten dan memperkuat Visibility UNRI. Diantara aplikasi-aplikasi pendukung yang sedang dikembangkan adalah

- SciHub UNRI merupakan aplikasi yang menghubungkan peneliti UNRI dengan flatform-flatform yang ada seperti SINTA, Google Scholar, Scopus, WOS dan Forlap. Tujuannya adalah sebagai 
sistem arsip (Self-archiving in Institutional Repositories) sehingga dapat meningkatkan dokumen peneliti UNRI yang disitasi sehingga meningkatkan nilai Exccelence dan Openness

- UNRI Knowledge Garden merupakan aplikasi repositori konten-konten yang digunakan untuk proses belajar mengajar, namun belum ada sistem yang mengakomodasi sehingga semua dokumen seperti bahan ajar, rencana perkuliahan semester, kontrak kuliah dan lain-lain. Dokumen-dokumen ini dapat meningkatkan nilai Openness.

C4. Membangun repositori institusi UNRI

Repositori institusi adalah sebuah sistem pengarsipan untuk mengumpulkan, melestarikan, dan menyebarluaskan salinan digital luaran intelektual suatu lembaga atau universitas, khususnya lembaga penelitian. Repositori institusional dapat dilihat sebagai serangkaian layanan yang ditawarkan universitas kepada anggota dosen dan karyawan untuk pengelolaan dan penyebaran materi digital yang dibuat oleh lembaga dan anggota komunitasnya. Contoh konten yang dapat dimasukkan adalah monograf, artikel ilmiah baik sebelum (preprints) dan sesudah (postprints) menjalani proses peer review serta skripsi, tesis dan disertasi elektronik. Repositori institusional juga dapat mencakup aset digital lain yang dihasilkan oleh akademisi, seperti kumpulan data, dokumen administratif, catatan kursus, objek pembelajaran, atau prosiding konferensi.

\section{C5. Pembersihan dan pengelolaan akun Google Scholar (GS) UNRI}

Nilai openness sangat tergantung kepada 300 orang peneliti teratas di GS UNRI. Menurut Webometrics.info hanya 210 peneliti yang digunakan, tetapi untuk mengantisipasi perubahan peringkat maka 300 merupakan jumlah yang aman. Dengan melakukan pengelolaan berupa bantuan teknis pembersihan dan monitoring artikel yang berada pada 300 peneliti teratas berarti menjamin bahwa UNRI akan mendapatkan poin pada faktor openness.

\section{C6. Implementasi Kebijakan Open Access Karya Ilmiah}

Implementasi Open Access (OA) memungkinkan siapa saja bebas langsung mengakses karyakarya ilmiah melalui internet tanpa membayar, sehingga sangat memudahkan pemustaka atau membaca untuk mengunduh karya tersebut secara full-teks, menyalin, mendistribusikan, maupun mencetak. Banyak keuntungan yang diperoleh dengan adanya gerakan OA di antaranya hasil penelitan memberikan dampak yang lebih besar, baik terhadap masyarakat, keilmuan dan semua faktor Webometric terutama excelence dan visibility. Selain itu, OA juga sebuah media yang berfungsi sebagai pusat arsip pekerjaan peneliti sehingga memudahkan penemuan dan penelusuran informasi ilmiah, memudahkan penyebaran informasi hasil penelitian, meningkatkan dampak dari penelitiannya, memungkinkan peneliti dapat mengetahui topik penelitian yang pernah dilakukan, dapat mengetahui tingkat pencapaian penelitian, maupun mengetahui tema penelitian yang masih belum tersentuh.

\subsection{Implementasi Strategi}

Agar implementasi strategi-strategi tersebut efektif, makaperlu dibuat skala prioritas. Penentuan implementasi berdasarkan tiga variabel yaitu impact atau pengaruh, waktu implementasi dan tingkat kesulitannya. Variabel impact adalah variabel yang menunjukkan pengaruh yang didapat jika langkah terseut berhasil dilakukan, variabel waktu implementasi adalah variabel yang menunjukan lama waktu penyelesaian implementasi sampai dapat dirasakan impactnya, dan variabel tingkat kesulitaan yang dilihat dari aspek finasial, tantangan dan hambatan dalam implementasi. Variabel-variablel tersebut diukur dalam skala likert danp engukuran dilakukan secara subjektif oleh peneliti dengan memperhatikan aspek-aspek SWOT pada tabel 7. Berdasarkan hasil pengukuran maka ditentukan prioritas langkah implementasi strategi. Hasil dari proses penilaian prioritas terkait disajikan dalam Tabel 8 .

Tabel 8. Hasil Analisis Prioritas Implementasi Strategi

\begin{tabular}{|c|c|c|c|c|c|}
\hline $\begin{array}{l}\text { LANGKAH } \\
\text { STRATEGI }\end{array}$ & IMPACT & $\begin{array}{c}\text { WAKTU } \\
\text { IMPLEMENTASI }\end{array}$ & $\begin{array}{c}\text { TINGKAT } \\
\text { KESULITAN }\end{array}$ & $\begin{array}{c}\text { NILAI } \\
\text { TOTAL }\end{array}$ & $\begin{array}{c}\text { PRIO } \\
\text { RITAS }\end{array}$ \\
\hline A1 & Kecil & Panjang & Sangat Mudah & 7 & 3 \\
\hline A2 & Besar & Sedang & Sulit & 7 & 3 \\
\hline A3 & Besar & Panjang & Sangat Sulit & 5 & 4 \\
\hline
\end{tabular}




\begin{tabular}{|c|c|c|c|c|c|}
\hline A4 & Sangat Besar & Panjang & Mudah & 8 & 2 \\
\hline A5 & Sangat Besar & Sedang & Sulit & 8 & 2 \\
\hline A6 & Sangat Besar & Sedang & Sulit & 8 & 2 \\
\hline A7 & Sangat Besar & Sedang & Sangat Mudah & 10 & 1 \\
\hline B1 & Besar & Sedang & Sulit & 7 & 3 \\
\hline B2 & Besar & Pendek & Sangat Mudah & 11 & 1 \\
\hline B3 & Sangat Besar & Pendek & Sangat Mudah & 12 & 1 \\
\hline B4 & Besar & Pendek & Mudah & 7 & 3 \\
\hline B5 & Besar & Sedang & Sulit & 7 & 3 \\
\hline B6 & Sangat Besar & Sedang & Sulit & 8 & 2 \\
\hline C1 & Sangat Besar & Panjang & Sangat Sulit & 6 & 4 \\
\hline C2 & Sangat Besar & Panjang & Sangat Sulit & 6 & 4 \\
\hline C3 & Besar & Panjang & Sangat Sulit & 5 & 4 \\
\hline C4 & Sangat Besar & Panjang & Sulit & 7 & 3 \\
\hline C5 & Sangat Besar & Panjang & Sangat Mudah & 9 & 1 \\
\hline C6 & Sangat Besar & Panjang & Sulit & 7 & 3 \\
\hline
\end{tabular}

Kegiatan implementasi strategi-strategi ini dilakukan dimulai dengan optimalisasi SEO (A4) dan membangun external link (B2) melaui aplikasi MyUNRI karena faktor Impact/Visibility merupakan faktor yang paling memiliki pengaruh besar dan relatif lebih mudah untuk ditingkatkan. Berdasarkan rencana implementasi strategi yang telah dilakukan (strategi A4 dan B2) menunjukan hasil bahwa berdasarkan data Webometric edisi Januari 2020 terjadi peningkatan peringkat Webometric UNRI dari peringkat 35 menjadi 31. Faktor utamanya adalah peningkatan aspek presence dari 1114 menjadi 986.

\section{Kesimpulan}

Dalam penelitian ini diusulkan sebuah kerangka strategi TIK dan langkah-langkah teknis untuk meningkatkan peringkat Webometric UNRI dengan cara menganalisis semua permasalahan yang terjadi di UNRI. Berdasarkan hasil penelitian dan pembahasan maka dapat ditarik kesimpulan bahwa belum efektifnya pengelolaan konten, infrastruktur dan SEO yang ada di UNRI mengakibatkan belum optimalnya sehingga banyak konten yang tidak terindek dan berpengaruh kepada peringkat Webometric Universitas Riau. Berdasarkan analisa faktor penilaian Webometric, faktor presence merupakan modal awal untuk meningkatkan faktor visibility dan openness, sehingga pengembangan faktor tersebut memiliki pengaruh terhadap peringkat Webometric. Selain itu, faktor Excelence dan Presence memiliki korelasi yang kuat dengan peringkat sebuah universitas, semakin tinggi nilai faktor tersebut maka akan semakin tinggi peringkat Webometric-nya.

Secara umum, perubahan metodelogi Webometric mempengaruhi peringkat sehingga perlu strategi TIK yang tepat untuk meningkatkan peringkat UNRI. Berdasarkan hasil analisa kesenjangan dan SWOT maka dirumuskan sebuah strategi TIK UNRI yang bertumpu pada tiga pilar utama yaitu pengembangan konten dan website, pengembangan interlinking dan penguatan publikasi riset untuk meningkatkan peringkat UNRI. Ketiga strategi tersebut harus didukung oleh pimpinan melalui kebijakan dan peraturan yang dibuat serta diperlukan sosialisasi yang intensif agar terciptanya kesadaran dilingkungan UNRI. Pada implementasinya, perbaikan infrastruktur, redesain dan optimalisasi mesin pencari, optimalisasi SEO dan membangun external link dapat memperbaiki peringkat Webometric dalam waktu yang relatif singkat, sedangkan penguatan aplikasi perpustakaan serta tata kelola dan implementasi kebijakan Open Access dimana kebijakan-kebijakan ini telah terbukti efektif pada universitas-universitas didunia membutuhkan persiapan jangka panjang.

Penelitian ini merupakan studi awal dalam peningkatan Webometric UNRI. Pengembangan selanjutnya adalah perlu dilakukan pengukuran keefektifitasan masing-masing strategi dan langkah- 
langkah yang telah diambil serta pembentukan peta jalan (roadmap) menuju implementasi kebijakan Open Access sehingga implementadi kebijakan Open Access dapat diterima semua pihak.

\section{Ucapan Terima Kasih}

Terima kasih penulis sampaikan Pimpinan dilingkungan Universitas Riau atas dukungan dan kerjasamanya serta Lembaga Penelitian dan Pengabdian kepada Masyarakat (LPPM) Universitas Riau yang telah memberikan dana Hibah Penelitian Bidang Ilmu Tahun 2020

\section{Referensi}

[1] A. Giannakoulopoulos, N. Konstantinou, D. Koutsompolis, M. Pergantis, and I. Varlamis, "Academic Excellence,Website Quality, SEO Performance: Is There A Correlation?," Futur. Internet, vol. 11, no. 11, pp. 1-25, 2019, doi: 10.3390/fi11110242.

[2] U. Rahardja, E. N. Dewi, and N. Lutfiani, "Peningkatan Rank Webometrics Menggunakan Metode Inbound Dan Outbound Pada Perguruan Tinggi," SISFOTENIKA, vol. 7, no. 1, Jan. 2017, doi: 10.30700/jst.v7i1.129.

[3] P. Ingwersen and L. Björneborn, "Methodological Issues of Webometric Studies," in Handbook of Quantitative Science and Technology Research, Dordrecht: Kluwer Academic Publishers, 2004, pp. 339-369.

[4] I. F. Aguillo, J. L. Ortega, and M. Fernández, "Webometric Ranking of World Universities: Introduction, Methodology, and Future Developments," High. Educ. Eur., vol. 33, no. 2-3, pp. 233-244, Jul. 2008, doi: 10.1080/03797720802254031.

[5] "Definition Of Ranking," Merriam-Webster, 2020. https://www.merriamwebster.com/dictionary/ranking (accessed Dec. 26, 2020).

[6] Isidro F Aguillo, "Combining Bibliometric and Webometric Information Web Ranking Methodology Under Scrutiny," 2013. https://digital.csic.es/bitstream/10261/131436/1/Webometrics_under_scrutiny.pdf.

[7] I. F. Aguillo, "Web , Webometrics and The Ranking of Universities," 2009.

[8] L. Björneborn and P. Ingwersen, "Perspectives of webometrics," Scientometrics, vol. 50, no. 1, pp. 65-82, 2001, doi: 10.1023/A:1005642218907.

[9] I. F. Aguillo, J. L. Ortega, M. Fernández, and A. M. Utrilla, "Indicators for A Webometric Ranking of Open Access Repositories," Scientometrics, vol. 82, no. 3, pp. 477-486, Mar. 2010, doi: 10.1007/s11192-010-0183-y.

[10] M. Thelwall, "Introduction to Webometrics: Quantitative Web Research for the Social Sciences," Synth. Lect. Inf. Concepts, Retrieval, Serv., vol. 1, no. 1, pp. 1-116, Jan. 2009, doi: 10.2200/S00176ED1V01Y200903ICR004.

[11] E. Romero-Frías, "Googling Companies - A Webometric Approach To Business Studies," Electron. J. Bus. Res. Methods, vol. 7, no. 1, pp. 93-106, 2009.

[12] M. Torres-Samuel et al., "Efficiency Analysis of the Visibility of Latin American Universities and Their Impact on the Ranking Web," 2018, pp. 235-243.

[13] K. H. Ramanayaka, X. Chen, and B. Shi, "Application of Webometrics Techniques for Measuring and Evaluating Visibility of University Library Websites in Sri Lanka," J. Univ. Libr. Assoc. Sri Lanka, vol. 21, no. 1, p. 1, May 2018, doi: 10.4038/jula.v21i1.7908.

[14] T. Lee-Hwa, A. Abrizah, and A. Noorhidawati, "Availability and Visibility Of Open Access Digital Repositories In ASEAN Countries," Inf. Dev., vol. 29, no. 3, pp. 274-285, Aug. 2013, doi: $10.1177 / 0266666912466754$.

[15] A. Hidayatullah, R. Pandiya, and C. Kartiko, "Analisis Usability Website Perguruan Tinggi Kota Jambi dengan Metode Entropi dan Topsis," in CENTIVE 2018, 2018, vol. 13, no. 2, pp. $157-162$.

[16] M. A. Damayanti, A. Sukmaaji, and S. Suhandiah, "Analysis Strategy Visibility And Activity At The Website Stikom.edu In Terms Of Increasing Ranked Webometrics," J. Sist. Inf. dan Komput. Akunt., vol. 5, no. 10, pp. 172-182, 2016.

[17] S. Susanto, "Strategi Menuju World Class University (WCU) Pada Universitas Semarang," J. Transform., vol. 11, no. 2, p. 86, Jan. 2014, doi: 10.26623/transformatika.v11i2.100. 
[18] N. Ramezanghorbani, M. Hajiabedin Rangraz, and R. Noot Heidari, "Some Effective Factors On The Webometric Status Of Selected Universities Of Medical Sciences: Lessons Learned from Iran," Iran. J. Public Health, vol. 48, no. 6, pp. 1116-1123, 2019, doi: 10.18502/ijph.v48i6.2923.

[19] B. Taheri, R. Ghazavi, A. Zahed, Z. Otroj, E. Mazaheri, and N. SoleimanzadeNajafi, "The Webometric Status of Isfahan University of Medical Sciences, Iran," Acta Inform. Medica, vol. 23, no. 4, p. 215, 2015, doi: 10.5455/aim.2015.23.215-219.

[20] H. Jati and D. D. Dominic, "A New Approach of Indonesian University Webometrics Ranking Using Entropy and PROMETHEE II," Procedia Comput. Sci., vol. 124, pp. 444-451, 2017, doi: 10.1016/j.procs.2017.12.176.

[21] S. Ariana, C. Azim, and D. Antoni, "Clustering of ICT Human Resources Capacity In The Implementation Of E-Government In Expansion Area: a case study from pali regency," Cogent Bus. Manag., vol. 7, no. 1, p. 1754103, Jan. 2020, doi: 10.1080/23311975.2020.1754103.

[22] R. Cahyaningsih, J. Magos Brehm, and N. Maxted, "Gap Analysis Of Indonesian Priority Medicinal Plant Species As Part Of Their Conservation Planning," Glob. Ecol. Conserv., vol. 26, p. e01459, Apr. 2021, doi: 10.1016/j.gecco.2021.e01459.

[23] M. Muliana and A. I. Said, "Combine Business Model Canvas, Blue Ocean Strategy, and Analytical Hierarchy Process to Develop Business Model of Malkita Mall Jakarta," 2020, doi: 10.2991/aebmr.k.200812.050.

[24] "Tahun 2019, Alumni Unri Mencapai 100.778 Orang," riaupunya.com, 2019. https://riaupunya.com/index.php/berita/18307/tahun-2019-alumni-unri-mencapai-100-778orang.html?utm_source=dlvr.it\&utm_medium=twitter. 